Shorter Article

\title{
Reconstruction of the Spanish money supply, 1492-1810
}

\author{
Yao Chen ${ }^{\text {a }}$, Nuno Palma ${ }^{\text {b,c,d }}$, Felix Ward ${ }^{\text {e,f,* }}$ \\ ${ }^{\text {a }}$ Erasmus School of Economics, Erasmus University Rotterdam, The Netherlands \\ ${ }^{\mathrm{b}}$ Department of Economics, University of Manchester, United Kingdom \\ ${ }^{\mathrm{c}}$ Instituto de Ciências Sociais, Universidade de Lisboa, Portugal \\ ${ }^{\mathrm{d}}$ Centre for Economic Policy Research, London, United Kingdom \\ e Erasmus School of Economics, Erasmus University Rotterdam, Burgemeester Oudlaan 50, 3062 PA Rotterdam, The Netherlands \\ ${ }^{\mathrm{f}}$ Tinbergen Institute, The Netherlands
}

\section{A R T I C L E I N F O}

\section{JEL classification:}

E31

E51

N13

\section{Keywords:}

Early modern period

Equation of exchange

Quantity theory of money

\begin{abstract}
A B S T R A C T
How did the Spanish money supply evolve in the aftermath of the discovery of large amounts of precious metals in Spanish America? We synthesize the available data on the mining of precious metals and their international flow to estimate the money supply for Spain from 1492 to 1810 . Our estimate suggests that the Spanish money supply increased more than ten-fold. Viewed through the equation of exchange this money supply increase can account for most of the price level rise in early modern Spain.
\end{abstract}

\section{Introduction}

This paper presents new times series for the Spanish money supply in the early modern period (1492-1810). This period has been interesting to economic historians and monetary economists alike. The influx of vast amounts of precious metals from Spain's American colonies, together with a rising price level, gave birth to early formulations of the quantity theory of money at the School of Salamanca. Today, research into the economic consequences of the inflow of American precious metals into Europe continues (Brzezinski et al., 2019; Palma, 2019, 2021). We hope that the money supply estimate we provide in this paper generates new inroads for the quantitative analysis of this unique period in monetary history. To estimate the Spanish money supply, we combine the available information on initial stocks with data on global mining output and international precious metal flows. The available information comprises data on the mining of precious metals in America and Europe, American retention of precious metals, precious metal flows across the Atlantic and Pacific (including transport losses), money outflows from Spain and Europe, and numismatic evidence on the wear of coins, as well as melt losses associated with their minting. To the best of our knowledge, we are the first to combine this information to obtain a money supply series for Spain in the early modern period. Throughout, we account for uncertainty about the underlying data by using stochastic simulations that translate data uncertainty into a probability distribution for the Spanish money supply. Our estimate suggests that the Spanish money supply, measured in tonnes of silver equivalent, increased more than ten-fold between 1492 and 1810.

\footnotetext{
He thank Kıvanç Karaman, Nicholas J. Mayhew, and Pilar Nogues-Marco, François R. Velde, as well as participants at various seminars and conferences for helpful comments. We are grateful to Carlos Álvarez-Nogal, Kıvanç Karaman, Leandro Prados de la Escosura, and Pilar Nogues-Marco for sharing their data with us. Any remaining errors are our own. Nuno Palma acknowledges financial support from Fundação para a Ciência e a Tecnologia (CEECIND/04197/2017). Replication data and codes are available at https://doi.org/10.3886/E139761V2 (Chen et al., 2021).

* Corresponding author.

E-mail addresses: y.chen@ese.eur.nl (Y. Chen), nuno.palma@manchester.ac.uk (N. Palma), ward@ese.eur.nl (F. Ward).
} 
While we focus on calculating the Spanish money supply, we also take a first look at what the new series implies for a long-standing question in monetary history: to what extent does money growth account for rising prices in the early modern period? We confirm that money growth accounts for most of Spain's price level rise between 1492 and 1810.

\section{Money and precious metal inflows in early modern Spain}

Coin in early modern Spain was commodity money. Silver was the most important monetary metal, although gold was used for coins of high denomination. ${ }^{1}$ Coins made of precious metals were more widely accepted than banknotes or bills of exchange (Nightingale, 1990). In continental European countries, precious metal coins typically accounted for more than half of the money supply as late as 1860 (Flandreau, 2004, p.3). For Spain in particular, gold and silver still made up around 85\% of the money supply in 1875 (Tortella et al., 2013, p.78). Our analysis therefore focuses on the narrow monetary aggregate consisting of gold and silver coins, which we interchangeably name "money" in the following. ${ }^{2}$

Spain's money supply was heavily influenced by the inflow of silver and gold from America (Desaulty et al., 2011). Annual Atlantic inflows were large, and primarily consisted of remittances, transfers of incomes from abroad, and capital inflows. Less than a third of precious metal inflows constituted payment for Spanish exports (based on total export values from Phillips, 1990, p.82). In terms of their functionality, liquidity, and acceptance as a means of payment, precious metal coins are comparable to narrow money aggregates today. In contrast to today's cash, early modern commodity money was not supplied by central banks, but minted by a mint on request of its customers. Precious metal mines were owned and run by private entrepreneurs (E1liott, 2006, p.93), and 85\% to $95 \%$ of precious metal remittances from the Spanish American colonies were privately owned (García-Baquero González, 2003; Costa et al., 2013). ${ }^{3}$ The government, however, owned the Imperial mints, set mint fees, decided upon which denominations to issue, and set the rate at which precious metals were exchanged for coin (the mint price). ${ }^{4}$

Commodity money possesses a higher intrinsic value than fiat money. This is because the same precious metals that are used to produce commodity money can also enter the economy's production function as intermediate inputs for the production of other goods such as silverware (Mayhew, 2012). Thus, when the commodity market value of precious metals rose above its mint price, an arbitrage profit could be realized by melting down coins and selling the metal on the commodity market. The primary function of American precious metals, however, was monetary. Regulation required all precious metals arriving from America to be brought to the Casa de Contratación. Private owners could pick up their silver from there, but had to submit a certificate of coinage from a mint of their choice within six months (Hamilton, 1934, pp.25, 29). ${ }^{5}$ At least from the 18th century onwards, most of Spanish America's mining output was directly minted in American mints (Céspedes del Castillo, 1996; Irigoin, 2020), and thus the vast majority of precious metals from Spanish America arrived in Spain as coins (Costa et al., 2013; de Paula, 2016, p.63).

\section{Money supply estimate}

\subsection{General methodology}

We calculate the Spanish money supply by combining an estimate of the Spanish money stock in 1492 with data on Spanish precious metal in- and outflows. To correct for the wear of coins we apply an annual depreciation rate of $0.24 \%$. This value lies at the center of the $0.2 \%$ to $0.28 \%$ range that numismatic research has established for the depreciation of coins through wear (Mayhew,

\footnotetext{
${ }^{1}$ Copper also played a monetary role in the form of small change. The prominence of copper money fluctuated over time (Motomura, 1994; Sargent and Velde, 2002). Only for a few decades after 1617 did copper coins make up a substantial share of the Spanish money stock (Velde and Weber, 2000a). Appendix B.3 summarizes the available quantitative information on the Spanish copper coin supply.

${ }^{2}$ Spain at the time was a composite monarchy under the same ruler. The dominant polities were Castile and Aragon. Our money supply estimate does not distinguish between different coins that existed in different parts of Spain (Mateu y Llopis, 1946, pp.253-274 provide an overview in this regard). Instead, we focus on the total money supply of Spain as a geographic entity in its modern borders.

${ }^{3}$ Only in the late 18th century did the Royal Treasury's share of precious metal remittances increase above $20 \%$.

${ }^{4}$ Spain's early modern network of mints was distributed across many cities (Burgos, Coruña, Cuenca, Granada, Segovia, Seville, Toledo, Valladolid). Total mint output, however, was highly concentrated in Seville (Mateu y Llopis, 1942; de Paula, 2016), which accounted for around 80\% of all coinage in the first half of the 17th century (Motomura, 1997). Spanish mints became less active over time, as silver was increasingly minted in America. According to de Paula (2016, p.366), only 6\% of Spanish silver arrivals in the 18th century were minted in Seville.

${ }^{5}$ For a precious metal flow to circumvent this regulation it had to be unregistered, i.e. smuggled. Unregistered inflows became important on the back of unregistered production between 1640 and 1720 (see Appendix A.3). In those decades, it is more likely that part of the precious metal inflow from America entered Spain for non-monetary use. Our stochastic simulation is informative about the extent to which this could influence the money stock estimate. This is because it accounts for the 1640-1720 rise in uncertainty surrounding unregistered production, which translates into rising uncertainty about Spanish inflows from America. To the extent that the amount of unregistered inflows was linked to the non-monetary use of metals, uncertainty about the former reflects uncertainty about the latter. As a consequence, the lower percentiles of the money stock probability distribution also delimit the effect that an increased non-monetary use of American precious metals could have on Spain's money stock estimate.
} 
1974; Velde, 2013). ${ }^{6}$ The initial stock $\left(M_{1492}\right)$, in- and outflows $\left(i n_{k}\right.$, out $\left.{ }_{k}\right)$ and depreciation determine the money supply $\left(M_{t}\right)$ :

$$
M_{t}=M_{1492}(1-0.24 \%)^{(t-1492)}+\sum_{k=1493}^{t}\left[\left(\text { in }_{k}-\text { out }_{k}\right)(1-0.24 \%)^{(t-k)}\right] .
$$

The money stock we calculate comprises gold and silver coins. It, therefore, is subject to a valuation effect deriving from gold-silver rate fluctuations. In early modern Spain, the price of gold vis-à-vis silver increased. As a consequence, the stock of gold coins expressed in silver equivalents increased. To account for this effect, we first calculate gold and silver stocks separately. ${ }^{7}$ Before adding them up, we convert the gold stock into contemporary silver equivalents using the Spanish Empire's official gold-silver rate (Cross, 1983, p.400). ${ }^{8}$

The data that enters the calculation of the Spanish money supply comes with a considerable degree of uncertainty. To account for this, we use stochastic simulations to accompany each point estimate of the Spanish money supply with a probability distribution. The setup of the stochastic simulation in accordance with the type and degree of data uncertainty we face is provided in Appendix A.1.

\section{Initial stock}

As the baseline estimate for Spain's initial money stock we use the mid-point of a range of initial stock estimates. The bounds of this range are demarcated by the estimates of Velde and Weber (2000b) and Jacob (1831). The discussion of initial stock estimates in Appendix A.2 shows how the values proposed by these authors emerge as the lower and upper bounds of plausible stock estimates at the eve of the early modern period.

According to Velde and Weber the global precious metal stock in 1492 amounted to 3600 tonnes of silver and 297 tonnes of gold. ${ }^{9}$ We calculate the Spanish part of this according to Spain's share of global economic activity (Bolt et al., 2018). Adding gold to the silver stock at Spain's official silver-gold rate results in 228 tonnes of silver equivalent. This is the lower bound value for Spain's initial money supply. Jacob's initial European stock value of 1749 tonnes of silver equivalent. According to Spain's share of European economic activity this translates into 565 tonnes of silver equivalent. ${ }^{10}$ The mid-point of the 228 to 565 tonne range - 396 tonnes of silver equivalent - serves as the baseline estimate for Spain's initial money stock. ${ }^{11}$

\section{Inflows}

The precious metal inflow series for Spain starts from the mining output data for Spain's American colonies (TePaske, 2010) (Appendix A.3). We transform this production data in the following way to arrive at Spanish precious metal inflows from America. First, we subtract the amount of precious metals that went directly from America to Asia (Bonialian, 2012; Borah, 1954; Chuan, 1969; Schurz, 1939) (Appendix A.4). Second, we account for the amount of precious metals that stayed in the Americas (Barrett, 1990; Irigoin, 2009; Walton, 1994, p.245). ${ }^{12}$ Third, we account for the loss of precious metals in maritime disasters and pirate attacks (Appendix A.5). Such losses could be large. In our sample they amounted to almost 5\% of all American production (Potter, 1972,

\footnotetext{
${ }^{6}$ Note that several other publications have chosen a 1\% depreciation rate (Motomura, 1997; Velde and Weber, 2000b). The value of $1 \%$, however, accounts for more varieties of precious metal loss than pure wear, e.g. transport losses and trade deficits (Mayhew, 1974; Patterson, 1972). Here, we focus on depreciation through wear, because our money stock measure separately accounts for trade-related precious metal outflows and transport losses. Undisclosed hoards are another reason for the disappearance of part of the money supply. Such hoards typically arise from emergency situations (especially wars) in which owners are unable to subsequently recover their hoard - either because they were permanently displaced, or because they did not survive the emergency. For example, early modern English hoards often stem from the English Civil War (Mayhew, 1995), and French hoards from the early years of the French Revolution (Velde, 2013). With the exception of Napoleon's Peninsular War after 1808, no similarly far-reaching conflict unfolded on Spanish territory. This lowered Spanish hoard owners' prospect of permanent displacement and unexpected death, and thus the incidence of undisclosed hoards in early modern Spain.

${ }^{7}$ While the gold and silver production data allow us to calculate separate gold- and silver inflows, we have to make assumptions about how various other flows (outflows, transport losses, and diffusion flows) were divided between gold and silver. We assume the allotments corresponded to the production shares. This ensures that the gold-silver composition of the Spanish money stock stays in line with mining output. This is broadly consistent with the observation that Spain's monetary system remained a bimetallic one throughout the early modern period, which implies that imbalances in the outflow of gold and silver must have been limited. We set the initial gold-silver share in accordance with the data by Velde and Weber (2000b).

${ }^{8}$ The Spanish Empire's official gold-silver rate was periodically adjusted to keep it in line with market rates across Europe. This is a necessary requirement to prevent the collapse of a bimetallic monetary system into a monometallic one according to the prediction made by Gresham's Law.

${ }^{9}$ Throughout the paper "tonnes" refers to metric tonnes.

${ }^{10}$ Given Spain's population level at the time, this translates into 106.6 grams of silver per person. The European countries upon which Spain's European GDP share is based include Belgium, Finland, France, Germany, Greece, Italy, the Netherlands, Poland, Portugal, Spain, Sweden, Switzerland, and England.

11 The use of GDP-shares as indicative of precious metal shares has some theoretical appeal. Assuming that purchasing power held in the long-run and that velocities did not differ substantially across countries, it follows from the equation of exchange, $M V=P Y$, that the international money stock distribution behaves according to real GDP-shares. The stochastic simulation that generates the money supply distribution allows for deviations from this theoretical baseline (Appendix A.1). As a consequence, the 95\% probability interval for 1492 ranges from 185 to 676 tonnes, which goes beyond the 228 and $565 \mathrm{t}$ values whose average forms the baseline estimate's initial value.

12 Barrett (1990, p.245) estimates that 15\% of American precious metal production was either retained in America or lost in transport. In our sample, transport losses amount to a bit less than $4 \%$ of American production. This implies a $11 \%$ retention rate for American precious metals. Similarly, data from the mint in Mexican City in the 1770 s shows that $75 \%$ of its output was exported to Spain, whereas the remaining $25 \%$ either stayed in America or went over the Pacific to Manila (Walton, 1994, p.181). In the 1770s around 7\% of American metals went over the Pacific,
} 
p.xix). Assuming that salvaged precious metals entered the European economy with a delay of one year, we add the amount of last year's salvaged precious metals to the American inflow measure. ${ }^{13}$

Transportation losses were initially borne by Spanish merchants. ${ }^{14}$ Thus, in the short-run, transportation losses first impacted the Spanish money supply. Over time, however, transportation losses probably diffused across borders: Spain's precious metal exports decreased, and its precious metal imports increased in the aftermath of a transportation loss. This type of diffusion is a standard feature of international monetary models, such as Hume's price-specie flow model (Hume, 1752), or the monetary approach to the balance of payments (Flynn, 1978; Frenkel and Johnson, 2013). We assume that in the long-run, Spain bore precious metal losses in proportion to its world GDP share. For the interim between short- and long-run, we implement a linear diffusion process that lasts for 10 years - a time span long enough to encompass short-term adjustment dynamics.

While Spanish America was the most important supplier of precious metals in the early modern period, mines in other regions continued to turn out non-negligible quantities of gold and silver. For example, silver mining in Europe experienced a boom in the early 1500s. ${ }^{15}$ Part of this non-Spanish precious metal output diffused into Spain. To account for this, we calculate the part of Central and Eastern European production that flowed into Spain according to Spain's share of European GDP, and add it to Spanish inflows. ${ }^{16}$ First, however, we subtract that part of the European production that did not diffuse within Europe but flowed to the rest of the world. We assume that newly produced European metals were subject to the same outflow rate as all other European precious metals. Thus, we set the fraction of the European production that flowed to the rest of the world $\left(\kappa^{E U, o u t}\right)$ equal to the European precious metal outflow-to-stock ratio, $\kappa^{E U \text {,out }}=$ out $_{t}^{E U} / M_{t}^{E U} \approx 0.79 \%$ (Attman, 1986; de Vries, 2003). ${ }^{17}$ We treat European precious metal arrivals from non-Spanish trading outposts and colonies, i.e. gold inflows from Africa and from Portuguese Brazil, analogously to European production (Morineau, 1985; TePaske, 2010). ${ }^{18}$

During the minting of coins, so-called melt losses consume part of the metal. Therefore, we remove one-time melt losses of $\lambda=0.52 \%$ from the production data to arrive at coin output (Mayhew, 1974, p.3). All in all, we calculate Spanish precious metal inflows as

$$
\begin{aligned}
i n_{k} & =\underbrace{\operatorname{prod}_{k-1}^{E S P}\left(1-\operatorname{retent}_{k}\right)(1-\lambda)-\text { pacific }_{k}-\operatorname{loss}_{k}+\operatorname{salv}_{k-1}}_{\equiv i n_{k}^{A M \rightarrow E S P}}+\text { diff use }_{k} \\
+ & \underbrace{\chi^{E U}\left(\operatorname{prod}_{k}^{E U}+i n_{k}^{R O W \rightarrow E U}\right)(1-\lambda)\left(1-\kappa_{k}^{E U, \text { out }}\right)}_{\equiv i n_{k}^{E U \rightarrow E S P}},
\end{aligned}
$$

leaving an American retention rate of $18 \%$. Up to 1780 we use the average of $11 \%$ and $18 \%$ as the American retention rate. Starting in the 1780 s the U.S. began to absorb an important fraction of American silver, as it inserted itself as a key intermediary in the trade networks linking Spanish America, with the Pacific and Atlantic economies. The U.S. cemented its role as a conduit for Spanish American silver during the Napoleonic wars. U.S. silver import data available for the 1820s suggest the U.S. imported on average 6.8 million pesos per year (Irigoin, 2009, Appendix I), whereas Spanish American production amounted to 26.2 million pesos per year on average between 1780 and 1810. The ratio of these two quantities amounts to $27 \%$ of Spanish American silver production. Adding the $27 \%$ U.S. absorption to the pre-1780s retention rate of $14.5 \%$ yields a $40.5 \%$ American retention rate. Between 1780 and the beginning of the Napoleonic wars in 1803 our final American retention rate linearly interpolates between these two figures.

${ }^{13}$ Instances when ships sank in very shallow waters and their treasure could be salvaged so quickly that it reached Spain without much delay are not included in the loss series. For example, the 1711 Nueva España fleet's treasure was quickly salvaged in this way (Marx, 1987, p.353), as was the treasure of Farfan's Tierra Firme Armada, which in 1555 stranded on Zahara beach, south of Cádiz (Potter, 1972, p.340). Only when salvaging operations dragged on for several months do we include losses into the loss series, and subsequently salvaged precious metals into the salvage series. We are aware of two events where salvaging operations lasted for more than one year. First, the salvaging of the 1715 loss continued until 1718, but returns to later salvaging operations rapidly diminished (Peterson, 1975, p.369). Second, the 1656 event, where repeated salvaging operations recovered part of the treasure, until shifting sands finally prevented further salvaging (Marx, 1987, p.316). Shifting sands were a more general problem that restricted the time horizon during which the lost treasure could be salvaged even if the ship sank in shallow waters. Marx (1987, p.424) mentions the San José shipwreck of 1631 in this regard. Thus, a 1-year lag due to salvaging was the most common scenario for the losses we consider. We make no attempt at adjusting for the more protracted salvaging operations associated with the 1656 and 1715 losses.

${ }^{14}$ By regulation, only Spanish merchants were allowed to engage in transatlantic business with the Spanish colonies (Nogues-Marco, 2011, p.6). Thus, although much of the precious metals arriving in Spain subsequently diffused throughout Europe, they first passed through a Spanish entity that was the initial owner.

${ }^{15}$ Mining in Spain itself, however, came to a halt after the discovery of the far richer mines of America.

${ }^{16}$ Up to 1600, the European production data comes from Nef (1941), whereas afterwards it comes from Soetbeer (1879). The data consists of bidecennial observations. We sum the linearly interpolated production data from all European regions to arrive at European precious metal production. We base our stock estimate on precious metal production data, rather than on official Spanish arrival data or mint output data for the following reasons: First, Spanish arrival data is less reliable (Appendix A.3), and data for the first 150 years on American minting is scarce. In addition, mint output data contains re-coinages, which leads to a double counting problem.

17 The calculation of the European stock, $M_{t}^{E U}$, is described in Appendix B.1.

${ }^{18}$ In contrast to American production, a significant fraction of European production and African inflows was not minted into coins. For the 16th and 17 th centuries, Jacob (1831) suggests that $20 \%$ was manufactured into ornaments or utensils. For the late 18 th century, especially after 1780 , Jacob (1831) puts this share at two thirds. Another estimate for 1688 by King (1696) puts it at $38.7 \%$. To account for this non-monetary use of precious metals, we subtract $20 \%$ of European production and African inflows up to 1688 . Between 1688 and 1780 , we subtract $38.7 \%$, and after 1780 we subtract $67 \%$. 


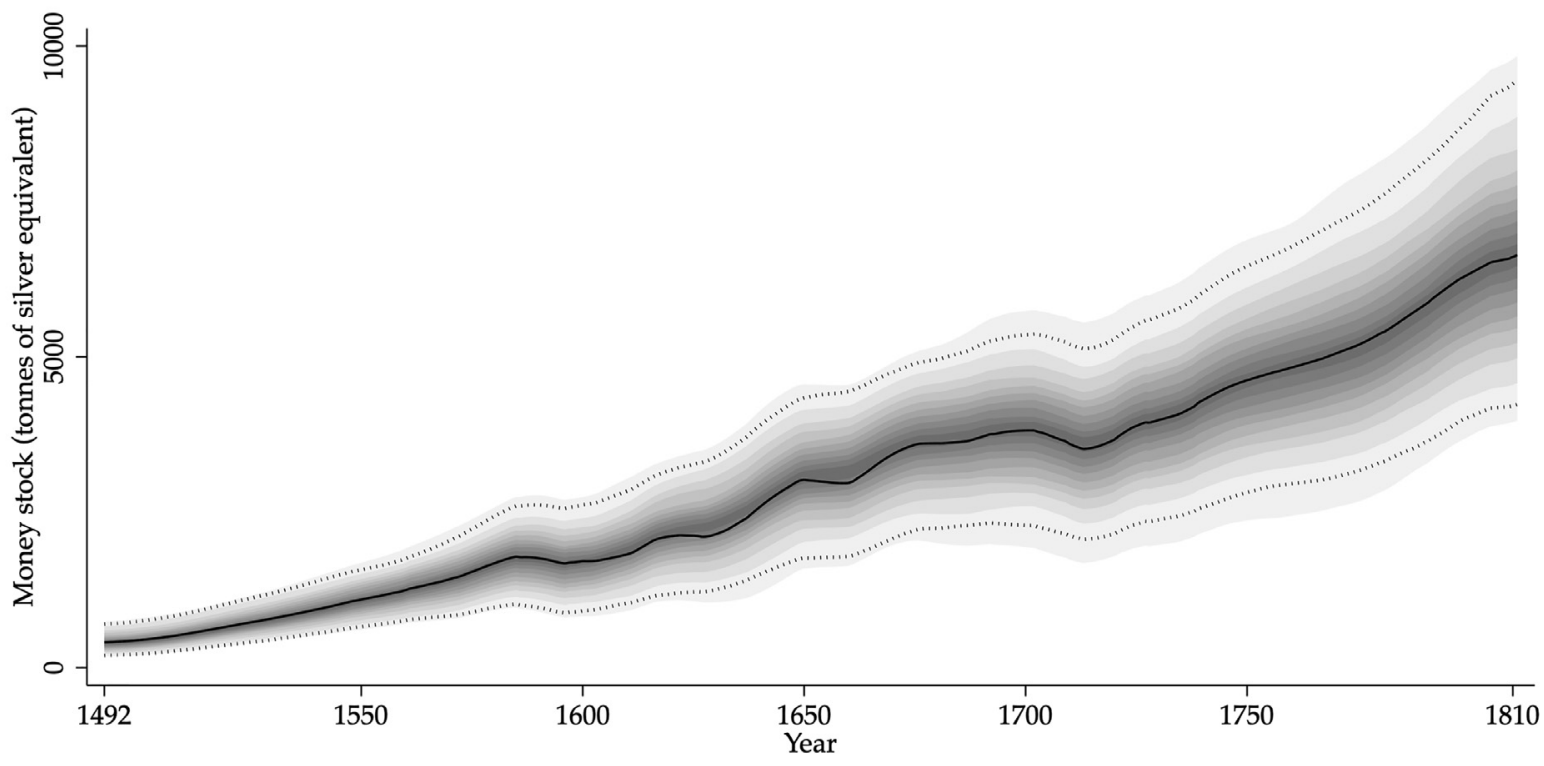

Fig. 1. Spanish money supply Notes: Lightest gray shade: $1 / 99$ th percentiles. Thereafter from light to dark gray: 5/95th to 45/55th percentiles. Dotted lines highlight 95\% probability interval. Distribution based on 10,000 draws from the input variable distribution. Centered 11-year moving average, neglecting missing observations at the borders.

where $i n_{k}^{A M \rightarrow E S P}$ and $i n_{k}^{E U \rightarrow E S P}$ are the summary terms for Spanish money inflows from America and Europe, respectively. prod ${ }_{k-1}^{E S P}$ is the Spanish-American production, ${ }^{19}$ retent $_{k}$ is the American precious metal retention rate, pacific $_{k}$ denotes precious metals leaving America through the Pacific, $\operatorname{loss}_{k}-s a l v_{k-1}$ are Atlantic transportation losses less previous year's salvaged treasure, dif $f u s e_{k}$ is the transportation loss diffusion term, $\operatorname{prod}_{k}^{E U}$ is the European precious metal production, $i n_{k}^{R O W \rightarrow E U}$ are other (non-Spanish) European precious metal arrivals, and $\kappa^{E U, o u t}$ is the fraction of the European precious metal production that leaves Europe every year. $\chi^{E U}$ denotes the sample average of Spain's European GDP share, which we calculate based on the real purchasing power adjusted GDP data from Bolt et al. (2018). Spain's European GDP share fluctuates between $13 \%$ and $18 \%$, with the sample average $\chi^{E U}$ equalling $15 \%$.

\section{Outflows}

Data on Spanish money outflows is relatively scarce. Attman (1986) and Walton (1994) provide the most comprehensive compilations in this regard. Their data indicates that the Spanish outflow ratio $\left(o_{k}\right)$ - the fraction of Spanish money inflows from America, which left Spain - hovered slightly above $90 \%$ for much of the 17 th century. In the late 17 th century, this share increased to $100 \%$. Only in the late 18th century did inflows systematically exceed outflows once again. ${ }^{20}$

During severe military conflicts, outflows could temporarily exceed inflows from America, which was the case during the height of the Dutch War for Independence and the War of Spanish Succession. We are unaware of any source for Spanish precious metal outflows before the late 16th century. Therefore, at the beginning of our sample, we work with a $91 \%$ outflow rate, which is representative of Spanish outflows in the 17 th and late 18 th centuries outside of periods of severe military conflict.

We use linearly interpolated values to bridge gaps in the Spanish outflow rate. The resulting series is displayed in Appendix A.6, together with the individual observations from Attman and Walton that underpin it. Based on the outflow ratio, $o_{k}$, we calculate Spanish money outflows as out $t_{k}=\left(i n_{k}^{A M \rightarrow E S P}+\operatorname{loss}_{k}-s a l v_{k-1}\right) o_{k}$, i.e. as a fraction of Spanish money inflows from America excluding transportation losses. This renders the outflows consistent with the previously introduced diffusion assumption. It is important to note that this series is painted with a broad brush and conveys no information about short-run variations in Spanish money outflows. It is, however, consistent with the trends lined out by the available data.

\section{Money supply}

By plugging the in- and outflow sequences, $\mathrm{in}_{k}$ and $\mathrm{out}_{k}$, into Eq. 1 we obtain the money supply estimate for Spain. Fig. 1 depicts the centered 11-year moving average of the resulting baseline estimate as a solid black line. Gray-shaded probability intervals show

\footnotetext{
19 The one-year lag reflects the time delay between the mining of precious metals in America and their and their entering of the monetary circulation in Spain.

20 Outflows in the following are expressed as a fraction of Spanish inflows from America. This normalization does not imply that all the precious metals that left Spain were necessarily of American origin. Where Attman (1986) and Walton (1994) state an absolute Spanish outflow value without accompanying inflow, we divide this value by our inflow measure ( $i n_{k}^{A M \rightarrow E S P}$ from Eq. 2).
} 
how the money supply estimate is affected by data uncertainty in the input variables (Appendix A.1). Dotted lines highlight the 95\% probability region.

According to the baseline estimate, the Spanish money stock increased from around 400 tonnes in 1492 to around 6400 tonnes in 1810. For much of the sample period the upper and lower bounds of the $95 \%$ probability region cover a $\pm 30 \%$ range around this level. At the beginning of the sample this range is wider, $\pm 50 \%$, reflecting the larger uncertainty about the initial stock level. By the late 1500 s the influence of the initial stock uncertainty has faded and the $95 \%$ bounds converge to the $\pm 30 \%$ range.

According to the baseline estimate, the Spanish money supply increased 16-fold between 1492 and 1810 . The corresponding increases for the upper and lower bounds of the $95 \%$ interval are 13-fold and 22-fold, respectively. To account for the possibility that money supply sequences begin near the lower bound of the distribution in 1492, and end near the upper bound of the distribution in 1810 we also calculate the $95 \%$ probability interval for Spain's early modern money supply increase. It ranges from ten-fold to 30 -fold, implying an average annual money growth rate between $0.7 \%$ and $1.1 \%$.

Fig. 1 depicts the money supply series as an 11 -year moving average. ${ }^{21}$ As a consequence, the series' low frequency variation is more reliable than its annual variation. Focusing only on the former, the Spanish money supply appears to have grown around a linear trend, with temporary stagnations occurring at the turns of the 17th and 18th centuries.

\subsection{Validation}

In this section we present several validation checks for the Spanish money supply estimate we propose. We begin by checking whether the velocity implied by the baseline estimate is plausible. We calculate velocity by dividing the Spanish nominal GDP series from Álvarez-Nogal and Prados de la Escosura (2013) by our baseline money supply estimate. The resulting velocity averages 2.6, and ranges from 1.3 to 4.8 . This is of similar magnitude as other velocity estimates for the early modern period. According to Mayhew (2013), velocity in England ranged from 2.2 to 8.7, whereas Palma (2018) locates it between 3.5 and 8.8. For the year 1526, Lindert (1985) proposes an English velocity range of 2.4 to 6.2; our Spanish velocity value for that year is 2.6.

Another way to validate the money supply estimate is to compare its 1810 end-point with money supply estimates for the 19 th century. For 1875, Tortella et al. (2013, p.78) report a Spanish money stock amounting to 7265 tonnes of silver equivalent. Our baseline estimate for 1810 is 6607 tonnes. This implies a modest money stock growth of $10 \%$ in the 65 years after $1810(0.15 \%$ per year). This is consistent with global events.

While silver inflows reached record levels in 1810, they collapsed afterwards (Tutino, 2018, p.244). This was due to British control of the Atlantic, the loss of Spanish control over its American colonies, and drastic declines in American silver production (Walton, 1994, p.196). In the turmoil following New Spain's (Mexico's) independence, its silver mining output remained at around half its 1810 level until 1840 (Tutino, 2017, p.175). On top of this, American retention rates increased as American populations grew quickly in the 19th century. ${ }^{22}$ Against this backdrop, the $95 \%$ interval's lower bound of 4285 tonnes for 1810 should be considered too low, because it implies that the Spanish coin stock grew at a similar rate after the independence of its American colonies as before. The actual 1810 money stock value is likely to lie closer to the baseline estimate. ${ }^{23}$

\subsection{Comparison to other money stock estimates}

How does our money supply estimate compare to other money supply estimates that have been proposed in the literature? For early modern Spain, two alternative approaches to estimating the money stock exist. The first approach approximates stocks by cumulating mint output over a period of time. The second approach counts mint output at a specific point in time - the late 18th century recoinage. This section discusses both these approaches.

Spooner (1972, pp.305-9), and later Challis (1978, pp.234-8), approximate a country's money stock by cumulating its mint output over 30 years. For Spain, this approach is more problematic than for other countries because it exported a large share of its mint output. Spanish mint output, thus, did not necessarily add to the Spanish money supply. Against this backdrop, it is perhaps not surprising that a 30-year cumulation of the gold and silver coin output of Spanish mints during the early 1600s results in an almost twice as high value as our baseline estimate (Motomura, 1997). ${ }^{24}$ Motomura himself notes that a substantial part of the coins minted during this period left Spain to finance military operations in the Low Countries. ${ }^{25}$ However, the more persistent economic reason

\footnotetext{
${ }^{21}$ Table D.1 in the Appendix tabulates the 11-year moving average series. Table D.2 shows the underlying annual series.

${ }^{22}$ More generally, in the 19th century, for many countries the amount of precious metals they attracted increasingly fell short of output growth. Partly this gave rise to deflation, partly this was compensated by the 19th century growth in non-metallic forms of money, such as bank notes and bank deposits.

${ }^{23}$ Carreras de Odriozola and Tafunell Sambola (2006, p.678), based on unpublished work by Tortella (n.d.), present another estimate for the Spanish stock of gold and silver coins in 1830 that amounts to 2214 tonnes of silver equivalent. The 1830 stock estimate is a mint output-based backward extension of stock estimates for the second half of the 19th century. As such, it is affected by the same problem as other mint output-based estimates of the Spanish money stock: As suppliers of an internationally accepted means of payment, Spanish mints produced more coins than were absorbed by the Spanish money stock, with the excess being exported. Thus, subtracting several decades of Spanish mint output to extend the Spanish money stock series backwards probably severely underestimates earlier stocks, as is pointed out by Tortella (n.d.) himself.

${ }^{24}$ Motomura (1997, Table 1, columns 5-6) separately reports minted gold and minted silver. We use the Spanish Empire's official gold-silver rate to convert gold weights into silver equivalent (Cross, 1983, p.400).

${ }^{25}$ The period after 1617 also witnessed a sharp increase in the issuance of copper money, which raises additional doubts about the applicability of the 30-year rule for the early 17 th century (Appendix B.3).
} 
behind the export of Spanish coins was their status as an internationally accepted means of payment (Irigoin, 2009). As such, Spanish pesos were used by various European trading companies for their East Asia trade. ${ }^{26}$

Tortella (n.d.) presents a stock estimate for 1775 which is equivalent to 563 tonnes of silver. This estimate is based on Spanish mint output during the Empire-wide recoinage of 1772 to 1778. It is important to notice that the recoinage was not compulsory for private holders (Hamilton, 1947, p.66). As a consequence, not all money was re-coined. For example, in the viceroyalties of New Spain (Mexico) and New Granada (Colombia) only between $28 \%$ and $50 \%$ of the local money stock was recoined (Moreno, 2014). This can explain why Tortella's stock value for 1775 lies substantially below our baseline value. The 1775 GDP estimate by Álvarez-Nogal and Prados de la Escosura (2013) provides another reason to prefer a higher money stock estimate for this year. The value of 563 tonnes implies a rather high velocity of 14.5 .

In sum, in contrast to previous stock estimates, our money supply series implies more plausible velocities. Furthermore, our money supply series connects initial stock estimates for 1492 to the more reliable stock estimates for the second half of the 19 th century. It does so based on a meticulous synthesis of the available data on the mining and international flow of monetary metals in the early modern period.

\section{What accounts for the early modern price level rise?}

We can use our money supply series to throw new light on a long-standing debate in monetary history: to which extent does money growth account for the early modern rise in European price levels? ${ }^{27}$ According to the monetarist view, rising price levels were primarily a consequence of rising money stocks, brought about by the influx of precious metals from America (Fisher, 1989; Hamilton, 1934; 1947; Mayhew, 1995). ${ }^{28}$ Another view highlights the role of an accelerating money velocity (Goldstone, 1984; 1991; Lindert, 1985; Miskimin, 1975): early modern increases in urbanization rates facilitated a larger number of economic transactions in any given time period - i.e. money velocity increased, pushing up the price level.

The money vs. velocity debate is commonly viewed through the lens provided by the equation of exchange:

$$
P_{t}=M_{t} V_{t} / Y_{t},
$$

where $P_{t}$ denotes the price level, $M_{t}$ the money stock, $V_{t}$ its velocity, and $Y_{t}$ stands for real output. While the equation of exchange is silent on the causal relationship of its constituent series, we can use identity 3 to account for Spain's price level rise in terms of money growth, velocity changes, and real output growth. To this end we use the importance measure $I(\cdot)$ :

$$
I\left(i_{t}\right)=\frac{\left|\Delta i_{t}\right|}{\left|\Delta m_{t}\right|+\left|\Delta v_{t}\right|+\left|\Delta y_{t}\right|}, \quad i_{t} \in\left\{m_{t}, v_{t}, y_{t}\right\},
$$

where small letters denote the natural logarithm of the respective variable, and $\Delta$ indicates changes over time. This importance measure assigns positive percentage contributions to $m_{t}, v_{t}$, and $y_{t}$, and ensures that they sum to unity, $I\left(m_{t}\right)+I\left(v_{t}\right)+I\left(y_{t}\right)=100 \%{ }^{29}$

To apply the accounting machinery lined out in Eqs. 3 and 4, we need data on prices, real output, money and velocity. Current best-practice estimates on the former two come from Álvarez-Nogal and Prados de la Escosura (2013). Their data, in combination with the new money supply estimate, allow us to back out velocity from the equation of exchange. We use the 11-year moving average GDP series by Álvarez-Nogal and Prados de la Escosura.

We generate the equivalent moving average for all other variables to avoid putting too much weight on individual annual observations at the beginning and end of the sample. This is particularly relevant for prices, which experienced double-digit growth rate gyrations after the onset of the Napoleonic Wars.

The following decomposition results reflects data uncertainty in the series for money, real GDP, and prices through $95 \%$ probability intervals for the importance measures, $I(\cdot)$. In particular, 10,000 random draws from the money supply distribution at the beginning and end of the sample reflect uncertainty in the money supply series. Analogously, we account for uncertainty in real

\footnotetext{
${ }^{26}$ As silver was increasingly minted in American mints, Spanish mints became less active over time. According to de Paula (2016, p.366), only 6\% of Spain's 18th century silver arrivals from America were minted in Seville - Spain's primary mint (Mateu y Llopis, 1942, p.51). Consequently, the 30-year sums of the Sevillian mint output data compiled by de Paula (2016) begin to lie substantially below the baseline stock estimate in the late 17 th and 18 th centuries.

${ }^{27}$ Here, we focus on the increase in silver prices, abstracting from changes in the silver value of the contemporary Spanish unit of account (UOA) - the Maravedí (Karaman et al., 2020; Pamuk, 2001). UOA prices rose more than silver prices due to debasements. The question whether early modern price inflation in Spain is accounted for by changes in the quantity of money or its velocity is more directly addressed by dropping the variable "silver per unit of account" from the analysis. The equation of exchange is easily translated from UOA units into silver units, because "silver per unit of account" enters on both sides - multiplying the price level $P_{t}$, and the money stock $M_{t}$. Dividing the equation of exchange by the silver content of one UOA thus allows us to abstract from changes in the silver value of the UOA.

${ }^{28}$ European prices modestly rose prior the arrival of large quantities of American precious metals. This has been attributed to an increase in production of European silver mines (Munro, 2003).

${ }^{29}$ As the equation of exchange is silent on the causal relationship between its four constituent variables, the importance measure results are consistent with different explanations for how money, velocity, real output, and prices are causally related to one another. For example, according to the quantity theory of money, the causal link runs from $m_{t}$ to $p_{t}$, for given $v_{t}$ and $y_{t}$. Palma (2019), however, argues that early modern money inflows rendered Spain's economy chronically uncompetitive, i.e. some of the importance of $y_{t}$ is causally attributed to $m_{t}$. Although the importance measure $I(\cdot)$ does not provide conclusive evidence in this regard, it does constitute a moment that is more readily matched by some theories than others.
} 
Table 1

Equation of exchange decomposition.

\begin{tabular}{lllll}
\hline Variable $i$ & Prices $(P)$ & Money $(M)$ & Velocity $(V)$ & Real GDP $(Y)$ \\
\hline Actual change & $\mathrm{x} 4.95$ & x 15.67 & x 0.89 & x 2.80 \\
Importance $I(\cdot)$ & & $\mathbf{7 0 \%}$ & $\mathbf{3 \%}$ & $\mathbf{2 6 \%}$ \\
& & {$[62 \%, 71 \%]$} & {$[0 \%, 14 \%]$} & {$[21 \%, 30 \%]$} \\
\hline
\end{tabular}

Notes: The percentage contributions may not add up to exactly $100 \%$ due to rounding. $95 \%$ probability interval in brackets.

output growth through random draws from uniform distributions at the beginning and end of the sample period. The range of these two uniform distributions is set according to the min-max range spanned by the three GDP estimates that Álvarez-Nogal and Prados de la Escosura (2013) provide for the years 1492 and 1810. Finally, to account for uncertainty about Spain's early modern price level, we use the alternative price indices that have been compiled by Allen (2001), Munro (2008) and Losa and Zarauz (2020). ${ }^{30}$ Unfortunately, these different price series lack overlap for the years 1492 and 1810 . Therefore, instead of using min-max ranges for these two years, we multiply the 1492 and 1810 price level values by Álvarez-Nogal and Prados de la Escosura with normally distributed error scalars with mean 1 and standard deviation $8 \%$. This mirrors the average percentage deviation of the three alternative price series from the price series by Álvarez-Nogal and Prados de la Escosura across all overlapping years.

To which extent can Spain's money growth account for its early modern price level rise? Table 1 shows the decomposition results. The first row reports the actual changes in prices, money, velocity, and real GDP. Prices increased by a factor of 4.95 and real GDP by a factor of 2.8. This was accommodated by a 15.6-fold increase in money, whereas velocity fell by $11 \%$. Put in terms of the importance measure described in Eq. 4, the money supply increase accounts for $70 \%$ of Spain's price level increase. The $95 \%$ probability interval of this importance measure stretches from $62 \%$ to $71 \%{ }^{31}$ By contrast, the $11 \%$ decrease in velocity accounts for only $3 \%$ of the change in prices (95\% interval: $0 \%$ to $14 \%$ ). The 2.8 -fold real GDP increase took substantial pressure off the price level (Nicolini and Ramos, 2010). Correspondingly, real GDP growth accounts for 26\% of the change in prices (95\% interval: 21\% to 30\%). Money growth thus accounts for more of Spain's early modern price level rise than velocity.

In sum, the results are consistent with money-based accounts of the early modern price level rise in Spain (Fisher, 1989; Hamilton, 1934). ${ }^{32}$ Spanish money velocity ends the early modern period at a level similar from where it began and consequently accounts for comparatively little of the price level rise over the whole sample. ${ }^{33}$

\section{Conclusion}

This paper presents a new long-run estimate of the Spanish money supply between 1492 and 1810 . The flood of precious metal inflows from America make this period a uniquely interesting episode for monetary historians to study. We arrive at an estimate of the Spanish money supply by combining data on the early modern production of precious metals and their international flow, with data on initial money stocks. The estimate suggests that Spain's money supply grew at an annual rate between $0.7 \%$ and $1.1 \%$. Viewed through the lens of the equation of exchange, the resulting money supply increase accounts for most of Spain's early modern price level rise.

\section{Appendix A. Data}

\section{A1. Uncertainty bands}

Economic data for the early modern period comes with uncertainty. We use stochastic simulations to generate a probability distribution for the Spanish money stock that reflects this uncertainty. More concretely, for uncertain input variables we specify a

\footnotetext{
30 The price series differ somewhat in their regional coverage, sample period, and goods basket composition, but their aggregate behavior is very similar to the index by Álvarez-Nogal and Prados de la Escosura (2013).

31 The interval is asymmetric around the baseline estimate because the importance measure is a non-linear function of the money stock. In particular, the importance measure's use of absolute values implies that equally sized increases and decreases in velocity obtain the same importance weight. Starting from a minimum weight of close to $0 \%$, velocity's importance can only go up. This is the case regardless of whether more money growth implies less velocity growth or whether less money growth implies more velocity growth. This asymmetry is inherited by the probability intervals of the other variables' importance measures.

32 Appendix C.1 explores the robustness of this finding with respect to the initial money stock. Only for an initial stock that exceeds the baseline initial stock value of 396 tonnes by $580 \%$ does the contribution of velocity begin to dominate the contribution of money growth - a tall order to overcome.

33 This leaves open the possibility that velocity changes mattered over shorter horizons, but that these velocity changes were subsequently reversed. In fact, the claim by Goldstone (1984) that an increase in velocity accounted for early modern price increases in the 16th and early 17th centuries, was accompanied by his claim that velocity decreases played an important role in Europe's subsequent 17th century deflations (Goldstone, 1991). Appendix C.3 shows subsample decomposition results that are consistent with Goldstone's velocity view for the case of Spain's deflation between 1651 and 1750.
} 
Table A.1

Input variable distributions.

\begin{tabular}{|c|c|c|c|}
\hline Input variable & Distribution & Parameterization & Notes/Sources \\
\hline Initial stock $\left(M_{1492}\right)$ & Uniform & $\mathcal{V}(\min , \max )$ & see text and Section A.2 \\
\hline \multicolumn{4}{|l|}{ Flows: } \\
\hline Pacific flow & Uniform & $V\left(\min _{t}, \max _{t}\right)$ & see Table A.3 \\
\hline European outflow (out $k_{k}^{E U}$ ) & $\mathrm{x}$ Normal & $\mathcal{N}\left(1,0.08^{2}\right)$ & Attman (1986); Barrett (1990); de Vries (2003) \\
\hline Spanish outflow rate $\left(\right.$ out $\left.{ }_{k}^{E S P}\right)$ & + Normal & $\mathcal{N}\left(0,0.05^{2}\right)$ & see text and Section A.6 \\
\hline Transport losses $\left(\operatorname{loss}_{k}\right)$ & x Normal & $\mathcal{N}\left(1,0.07^{2}\right)$ & Mangas (1989) \\
\hline \multicolumn{4}{|l|}{ Production: } \\
\hline American production $\left(\operatorname{prod}_{k}^{E S P / P R T}\right)$ & $\mathrm{x}$ Normal & $\mathcal{N}\left(1, \sigma_{t}^{2}\right)$ & see text and Section A.3 \\
\hline European production $\left(\operatorname{prod}_{k}^{E U}\right)$ & $\mathrm{x}$ Normal & $\mathcal{N}\left(1,0.1^{2}\right)$ & see text \\
\hline African inflows $\left(i n_{k}^{A F R \rightarrow E U}\right)$ & $\mathrm{x}$ Normal & $\mathcal{N}\left(1,0.1^{2}\right)$ & see text \\
\hline \multicolumn{4}{|l|}{ Other: } \\
\hline Depreciation & Uniform & $\mathcal{V}(0.20 \%, 0.28 \%)$ & Mayhew (1974) (annualized) \\
\hline American retention rate & + Uniform & $\mathcal{V}(-0.035,0.035)$ & see text \\
\hline Mint rate & + Uniform & $\mathcal{V}(-0.15,0.15)$ & see text \\
\hline Spain's European GDP share 1 & + Uniform & $\mathcal{V}(-0.025,0.025)$ & see text \\
\hline Spain's European GDP share 2 & + Uniform & $\mathcal{V}(-0.05,0.05)$ & Bonfatti et al. (2020) \\
\hline
\end{tabular}

Notes: x: multiply with error scalar. + : add error term.

probability distribution that reflects the type and degree of uncertainty we face in the data sources. We then repeatedly calculate the Spanish money stock based on random draws from the input variables' distribution. ${ }^{34}$ The result is a time-varying distribution of the Spanish money stock that reflects data uncertainty. This approach also allows us to report probability intervals for all our results. An overview of the distribution of input variables can be gleaned from Table A.1. The rest of this section discusses the specification of this distribution.

We account for uncertainty about the initial money stock by defining a min-max range that corresponds to the range of initial stock estimates in the literature. Section A.2 summarizes and discusses these estimates. The initial stock values by Velde and Weber (2000b) and Jacob (1831) emerge as lower and upper bounds that delimit the set of plausible initial stock values. The upper bound value of 565 tonnes exceeds the lower bound value of 228 by around $250 \%$. We take random draws from an accordingly delimited uniform distribution to reflect initial stock uncertainty.

To account for uncertainty in Pacific flows we use period-specific range estimates for how many million pesos were carried by the Manila galleons. Range estimates are wide, with upper bounds commonly exceeding lower bounds by $100 \%$. Section A.4 discusses the underlying data, and Table A.3 lists the period-specific ranges. Absent prior information about how Pacific flows are distributed within these ranges, we draw from period-specific uniform distributions. Draws are conducted independently for each of the sub-periods.

To reflect the uncertainty in precious metal outflows from Europe we randomly draw an error scalar from a normal distribution whose standard deviation reflects the dispersion seen in the literature. Our baseline series for European outflows uses data from Attman (1986) and de Vries (2003). In particular, we use Attman's estimates for precious metal flows across the Baltic and Levant, and de Vries' revision of direct flows to East Asia via the Cape route. Barrett (1990) has also compiled a European outflow series. ${ }^{35}$ Barrett's series is very similar to the series proposed by de Vries and Attman up to the mid 18th century.

After that, Barrett's series misses the Cape route flows of several European trading companies, and thus underestimates the direct flow from Europe to East Asia. The standard deviation of the discrepancy between Attman's outflow series for Europe and our baseline outflow series is $7.6 \%$. With respect to Barrett's outflow series the equivalent figure up to the mid 18th century, when Barretts series begins to systematically underestimate Cape route flows, is $8 \%$. We therefore set the standard deviation of the normally distributed scalar to $8 \%$ of our baseline outflow figure. Error terms are drawn independently for each observation, i.e. 25-year periods.

To the Spanish outflow rate, we add a normally distributed error term with a 5 percentage point standard deviation. This captures the large uncertainty surrounding the Spanish outflow data. More concretely, the standard deviation of the difference between our baseline outflow rate series (Fig. A.5) and the individual outflow observations provided by Walton (1994) and Attman (1986) is 4.7 percentage points. The available data is laid out in Section A.6. The error term is drawn independently for each observation, i.e. each of the constituent sub-periods displayed in Table A.5. The calculation of interpolated values then proceeds based on the current set of random draws for each sub-period.

Transportation loss data are subject to uncertainty because of unregistered shipments. Private treasure flows were taxed upon arrival in Spain and thus there existed an incentive for smuggling. The data collected by Mangas (1989, p.316) and Morineau (1985, pp. 242 and 375) suggests that, on average, smuggling amounted to $30 \%$ of registered shipments in the 16 th century, $67 \%$ in the 17 th century, and $47 \%$ in the 18th century. The standard deviation in the smuggling rate amounts to 7 percentage points (based on 27 observations for the 17th century from Mangas (1989)). We therefore multiply the smuggling rate for each transportation loss with

\footnotetext{
${ }^{34}$ We take 10,000 draws from the joint distribution of input variables. This is sufficient to ensure that the resulting money stock distribution has converged. Draws are independent across input variables. A stochastic simulation that incorporates additional covariance across input variables is discussed in Appendix C.2.

35 The European outflow series compiled by Morineau (1985) neglects precious metal flows across the Baltic, and thus is systematically too low (Attman, 1986, p.75).
} 
a normally distributed scalar that is centered around 1 and has a standard deviation of $7 \%$. We draw this scalar independently for each loss event.

The main source of uncertainty about the American precious metal output pertains to the amount of unregistered production that took place. Section A.3 provides a detailed discussion of this subject and the available data. To account for the uncertainty introduced by unregistered production, we multiply the American production data (including average estimates for illicit production) with a normally distributed error scalar, whose standard deviation mirrors the dispersion between different production series. In particular, we set the error scalar's standard deviation to $10 \%$ for the periods prior to 1640 and after 1720 . Between 1640 and 1720 we apply a higher standard deviation of $15 \%$ to reflect the higher degree of uncertainty surrounding the amount of unregistered production during this time period. These period-specific standard deviations reflect the discrepancy between the production series by Humboldt (1811), which includes illicit production, and our baseline production series, which adds an estimate of illicit production to the comprehensive official production data by TePaske (2010) (see Fig. A.1). Error scalar draws are independent across the three sub-periods, 1492 to 1639,1640 to 1720 , and 1721 to 1810 .

With regard to the European precious metal production the estimates by Soetbeer (1879) have been taken over by much of the subsequent literature (Merrill, 1930; Ridgway, 1929; Velde and Weber, 2000b). Only the pre-1600 data has been substantially revised upwards by Nef (1941). However, this lack in variance in the literature cannot be interpreted as the absence of uncertainty about European production figures. We therefore multiply the European production data with an error scalar that has a standard deviation of $10 \%$ and a mean of 1 . The error scalar is drawn independently for each 20-year period observation by Soetbeer and Nef. We follow the same approach for the African precious metal inflows by Morineau (1985).

We reflect uncertainty about the depreciation rate of money due to the wear and tear by a uniform distribution with limits set according to the $0.2 \%$ to $0.28 \%$ range described by Mayhew (1974). Our estimate of the American retention rate up to 1780 is $14.5 \%$. This fraction is an average based on observations by Barrett (1990) and Walton (1994). Barrett estimates that 15\% of the American precious metal production either stayed in America, or was lost in transport. We subtract transportation losses from the $15 \%$ figure to arrive at American retention. Thus the American retention rate inherits uncertainty from transportation losses, and the American precious metal production series. The other observation comes from the mint in Mexico City. In the 1770s it exported $75 \%$ of its mint output to Spain (Walton, 1994, p.181). The remaining 25\% either went over the Pacific or stayed in America. We subtract the contemporary Pacific flow rate of around $7 \%$ from the $25 \%$ figure to arrive at American retention. To the extent that the exact Pacific flow is uncertain, the American retention rate inherits this uncertainty. In addition, we add a uniformly distributed random error term from the $+/-3.5$ percentage point range to the American retention rate. This 7 percentage point range spans the difference between the $11 \%$ retention rate estimate based on Barrett (15\% minus a $4 \%$ average transportation loss), and the $18 \%$ rate based on the Mexican mint data ( $=25 \%$ minus a $7 \%$ mid-point pacific flow estimate). For each calculation run, the error term is drawn once for the entire retention rate series from 1492 to 1810 .

The uncertainty surrounding the rate at which the European precious metal production and African arrivals were minted is reflected in a uniformly distributed error term that ranges from -15 to +15 percentage points. This large variance is warranted because the mid-point estimates by Jacob (1831) and King (1696) are at best educated guesses. Thus, for the period from 1492 to 1687 the share of unminted metals is equally likely to be any number between $5 \%$ and $35 \%$. For 1688 to 1779 the range is $24 \%$ to $54 \%$, and from 1780 onwards it is $52 \%$ to $82 \%$.

Finally, the use of Spain's share of European GDP in the money supply estimate is associated with two types of uncertainty. First, there is data uncertainty about the exact value of Spain's European GDP share in the early modern period. The data by Bolt et al. (2018) imply an average share of 15\%. However, shares vary between $13 \%$ and $17.5 \%$ depending on time period and underlying source. The stochastic simulation reflects this uncertainty by adding a uniformly distributed error term from the $+/-2.5 \%$ range to Spain's 15\% average GDP share.

The second type of uncertainty pertains to the extent to which Spain's European GDP share is representative of intra-European precious metal diffusion. This is because the money supply estimation assumes that intra-European precious metal diffusion from the rest of Europe into Spain corresponds to Spain's European GDP share. ${ }^{36}$ To cover the uncertainty associated with this assumption we add a second error term to Spain's average GDP share of 15\%. We opt for a uniformly distributed error term whose support spans the $+/-33 \%$ range around the $15 \%$ baseline. This treats the GDP share of $15 \%$ as equally representative of precious metal diffusion shares in the $10 \%$ to $20 \%$ range. The choice of this range is motivated by Bonfatti et al. (2020) according to which the money holdingsto-income ratio of Europe's most monetized economies tended to be no more than two times the money holdings-to-income ratio of Europe's least monetized economies. The two error terms for Spain's European GDP share are drawn once for the whole sample. Spain's initial stock estimate inherits this error term to the extent that it uses Spain's European GDP share to translate European stocks into Spanish stocks.

\section{A2. Initial stock}

The earliest known estimate of the European precious metal stock comes from economic statistician King (1696). King puts the total stock of precious metals at 45 million pound sterling. According to his data for the late 1600 s, $61.3 \%$ of that was in minted form.

\footnotetext{
${ }^{36}$ In particular, the Spanish money supply estimate incorporates parts of the following quantities according to Spain's European GDP share: the non-Spanish European precious metal production, the non-Spanish European precious metal arrivals, and transport losses.
} 
Table A.2

Initial precious metal stock in 1492 .

\begin{tabular}{|c|c|c|c|}
\hline Source & Region & Silver equivalent & Notes \\
\hline \multicolumn{4}{|l|}{ Early authorities: } \\
\hline King (1696) & Europe & $3073 \mathrm{t}$ & minted silver and gold \\
\hline Hume (1752) & Europe & $1489 \mathrm{t} / 6679 \mathrm{t}$ & pesos / pound sterling (unclear unit) \\
\hline \multicolumn{4}{|l|}{ Production-based: } \\
\hline Jacob (1831) & Europe & $3749 \mathrm{t}$ & Roman money stock and production/depreciation assumptions \\
\hline Velde and Weber (2000b) & World & $6603 \mathrm{t}$ & cumulated production since neolithic age \\
\hline \multicolumn{4}{|l|}{ Equation-based: } \\
\hline Gallatin (1830) & Europe & $7818 \mathrm{t} / 3228 \mathrm{t}$ & 1492 real money stock $=1596$ real money stock $/$ revised estimate \\
\hline Braudel and Spooner (1967) & Europe & $74,854 \mathrm{t}$ & gold stock value $=$ silver stock value \\
\hline \multicolumn{4}{|l|}{ Secondary estimates: } \\
\hline Del Mar (1877b) & Europe & $3749 \mathrm{t}$ & based on Jacob (1831) \\
\hline Glassman and Redish (1985) & Europe & $3542 \mathrm{t}$ & average of Del Mar (1877b) and King (1696) \\
\hline Morineau (1985) & Europe & $15,000 \mathrm{t}$ & erroneous translation of Hume (1752); unclear conversion rate \\
\hline
\end{tabular}

Notes: Stock figures refer to metric tonnes of silver equivalent.

This translates into 3073 tonnes of minted silver equivalent. Unfortunately, King does not provide information on how he arrived at his initial stock figure.

Other estimates of precious metal stocks for 1492 can be categorized into three groups: production-based estimates, equationbased estimates, and secondary-literature values. Among the first group are Jacob (1831) and Velde and Weber (2000b). Jacob puts the initial European stock at 33,674,256 pound sterling (3,749 tonnes of silver equivalent). He arrives at this quantity based on a Roman money stock figure put forth by Sueton for the time of Vespasian's reign. This figure is then depreciated at an annual rate of $1 / 360$ up to the early 9th century, at which point the resumption of European precious metal production is assumed to exactly offset any further depreciation up to the early modern period.

The timing of these assumptions has been broadly confirmed by McConnell et al. (2018) based on traces of antique lead pollution that are recognizable in Greenland ice cores today. However, the depreciation rate of $1 / 360$ has been criticized as too low, because it only reflects the wear and tear of coins in normal times (Chevalier, 1847, pp. 68-69). This neglects, among others, transportation losses and lost hoards. When these are taken into account, money stocks depreciated at a faster rate (MacCulloch, 1855, p.1054). For this reason, Velde and Weber (2000b) apply a higher depreciation rate of $1 \%$ to arrive at a global precious metal stock through the cumulation of precious metal production. This $1 \%$ depreciation rate is endorsed by Patterson (1972) as a plausible catch-all rate of depreciation. Velde and Weber arrive at a global stock of 6897 tonnes of silver equivalent in 1492.

The second group of initial stock estimates uses additional assumptions to back out initial stocks. Braudel and Spooner (1967) assume that in 1500 and in 1660 the value of the European gold stock equals the value of the European silver stock. Combining this assumption with a European net-inflow of 181 tonnes of gold and 16,886 tonnes of silver between these two years and a gold silver ratio of 10.5 in 1500 and 14.5 in 1660 they obtain initial European stocks for gold, $G_{1500}$, and silver, $S_{1500}$, as the solution to the following two equations:

$$
10.5 \cdot G_{1500}=S_{1500}
$$

$$
14.5 \cdot\left(G_{1500}+181.3\right)=G_{1500}+16,886
$$

The arbitrariness inherent in this approach has been pointed out by many authors, including Braudel and Spooner themselves. The assumption that the value of the gold stock equals the value of the silver stock lacks grounding in economic theory (Glassman and Redish, 1985; Morineau, 1985; Palma, 2019). In addition, the resulting initial stock value of 74,854 tonnes of silver equivalent is so high that it defies the available production side data. Morineau (1985) points out that accumulating this stock would have required all European mines to operate at their peak 16th century capacity since antiquity, and even then a zero depreciation and outflow assumption would be needed to reach such a high stock level for 1492.

The estimate by Gallatin (1830) uses a value of American precious metal inflows of 800 million USD until 1596 and a 3.5-fold increase in goods prices, $P$, to derive a 1492 precious metal stock, $M_{1492}$, for Europe of around 300 million USD (evaluated in 1830 USD). While Gallatin does not explicitly state how he deducts the latter from the former, his writing suggests that he assumes the real money stock, $M / P$, to be constant:

$$
\frac{M_{1492}}{P_{1492}}=\frac{M_{1492}+800}{3.5 \cdot P_{1492}}
$$

Solving this equation for $M_{1492}$ yields the proposed initial stock value around 300 million USD, translating into around 7800 tonnes of silver equivalent. While this value is substantially smaller than the one obtained by Braudel and Spooner (1967) and thus conforms more closely to production side estimates, its grounding in economic theory is similarly weak.

To explore the assumptions involved, first consider the equation of exchange for Europe: $M V=P Y$. A constant real money stock involves a constant ratio of real output over velocity, $Y / V$. This is hard to justify even when assuming a stable velocity, $V$, and a 
Malthusian constancy of real output per capita. This is because Europe experienced population growth of around $30 \%$ in the 16 th century, which increased real output, $Y$. Second, the proposed stock addition of 800 million USD/20,000 tonnes of silver equivalent neither takes cumulated European production nor cumulated European outflows into account. According to our estimates the former amounts to 6200 tonnes, and the latter to 5300 tonnes. In addition there was a small inflow from Africa, amounting to around 820 tonnes. Finally, the proposed American inflow value of 20,000 tonnes exceeds our best estimate of 8700 tonnes by more than $100 \%$. When we revise the Gallatin estimate by these factors - population growth, European outflows, European production, African inflows, and lower cumulated inflows from America - we arrive at a revised initial European stock estimate of 3228 tonnes - a value not far from Jacob's production side estimate.

Next, there exists a secondary literature on precious metal stock estimates for Europe at the eve of the early modern period. Del Mar (1877b, p.40) states a value of 167 million USD, which is a USD-translation of Jacob (1831) at a USD-pound sterling exchange rate of 4.96 (see Del Mar, 1877a, pp.71ff.). ${ }^{37}$ Glassman and Redish (1985) average the initial stock estimates by King (1696) and Del Mar (1877b) to initialize their European stock. By construction, their estimate thus lies within our preferred initial stock range. The initial European stock value used by Morineau (1985, p.571) - 60 million pound sterling/15,000 tonnes - is a curiosity: First, it is based on a French translation of Hume (1752), but, as has been pointed out by Stengers (2004), the value of 60 million pound sterling is not contained in Hume's original work. It has been introduced by a loose French translation. Second, equating 60 million pound sterling into 15,000 tonnes of silver equivalent implies an inexplicable conversion rate of $250 \mathrm{~g}$ of silver per pound sterling. For these reasons it is hard to justify the 15,000 t figure.

Hume's original text states that an annual precious metal inflow from America to Europe amounting to 6 million per year would probably have doubled the initial European money stock within ten years (6 million times ten years equals 60 million). ${ }^{38}$ Importantly, Hume's original text does not specify the unit, and "million" might well refer to Spanish pieces of eight (pesos), which would bring it in line with inflow data for the early 16th century. Even at the time of Hume's writing, in the mid-18th century, an inflow value of 6 million pound sterling is too high. European precious metal inflows from America only reached that level around 1800. The peso interpretation of Hume would yield an initial European stock of around 1500 tonnes of silver equivalent - a value in the vicinity of that implied by Velde and Weber (2000b). The pound sterling interpretation of Hume's figures yields a silver weight of around 6500 tonnes - somewhat below the number yielded by the equation-based approach of Gallatin (1830).

In sum, the literature provides various estimates of initial precious metal stocks around 1500. Our preferred estimates are the production-based ones. Although they require heroic assumptions, their methodological basis is in principle sound. The productionbased estimates receives additional support from two sides: First, the revised initial stock springing from the real money stock assumption of Gallatin (1830) falls within the range spanned by the two production-based estimates. Second, the production-based estimates furthermore align with the stock estimates proposed by King (1696) and Hume (1752) - the two earliest authorities on the matter.

\section{A3. American production and European arrivals}

Different sources on American precious metal production exist. While they agree about the amount of American precious metal production for the 16th and 18th centuries, they disagree for the 17th century. Sources that account for unregistered precious metal production show substantially higher numbers than sources that focus only on officially registered production (Barrett, 1990). For our calculations, we use the official production data from TePaske (2010), which is the most comprehensive yet compiled. ${ }^{39}$ Fig. A. 1 shows this data and compares it to the production data by Humboldt (1811), who takes unregistered production into account. There is a substantial deviation between these two series from the mid 17th century to the early 18th century.

Given that some of the sources that Humboldt used to construct his production series are unknown today, it is worth considering a second piece of evidence about the quantity of unregistered precious metal production: the amount of American precious metals that was arriving in Europe. This data was regularly published in contemporary Dutch gazettes that have been unearthed by Morineau (1985). In the 17th century, the European arrival data at times exceeds the official American production data, suggesting a considerable amount of unregistered production took place in America. Morineau's arrival data and Humboldt's production data reinforce each other in this regard (Barrett, 1990). We therefore adjust the official production data from TePaske for unregistered production.

To account for unregistered precious metal production we add $16.8 \%$ to the production series by TePaske - the adjustment factor calculated by Humboldt (1811). From the mid-17th century to the early 18th century the share of unregistered production was higher, reaching up to $50 \%$ (TePaske, 2010, pp.311ff.). We thus use a 50\% adjustment factor for the period $1640-1720 .{ }^{40}$ From 1720 , up to

\footnotetext{
37 Note that translating the Del Mar USD value back into silver weights at either the USD's peso parity, or using the USD gold price together with the gold-silver ratio can result in somewhat higher stock values. This explains the discrepancy between the silver weight translations of the values by Del Mar and Jacob that can be found in the literature (Glassman and Redish, 1985).

${ }^{38}$ In earlier editions of Hume's work the respective numbers were 7 million and 5 years.

39 At the beginning of our sample (up to 1555), where TePaske only provides decadal averages, we draw on Jara (1966) for annual production data.

${ }^{40}$ During this period, the reduced supply of mercury to Mexican amalgamators facilitated an increase in illicit production. More refining was done using smelting, which made it easier to hide the exact amount of silver production from the fiscal authority. Brading and Cross (1972) note that due to the shortage of mercury just under half of Zacatecas's silver was produced using smelting in the years 1685-1705. At Sombrerete, none of the silver was produced using amalgamation. In Peru, although the official production data shows a decline starting in the 1640s, mercury consumption
} 


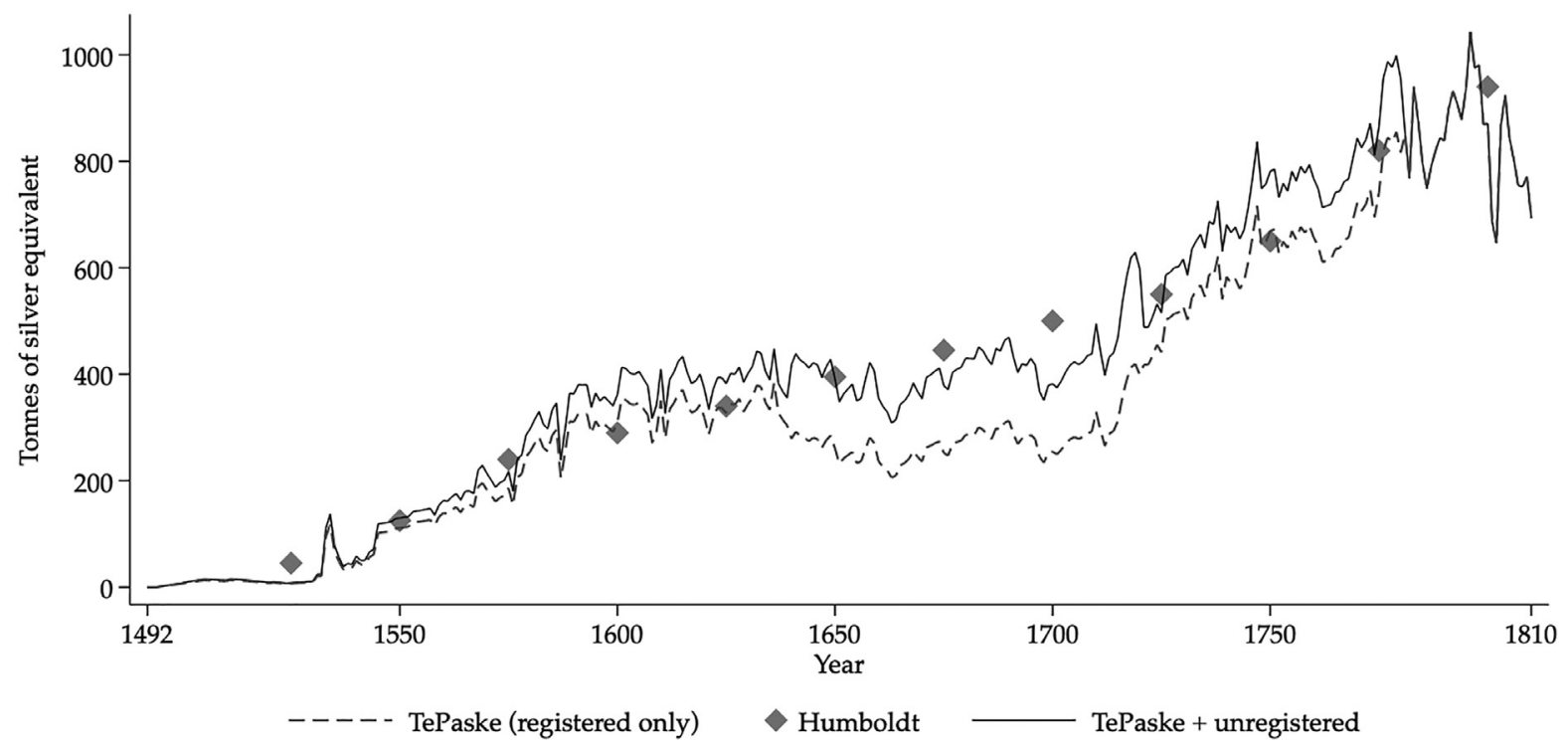

Fig. A.1. American precious metal production.

the late 18th century we switch back to $16.8 \%$. Finally, by the late 18 th century less and less production escaped registration by the Spanish Empire's reformed bureaucracy. Therefore, from 1780 onwards we set our adjustment factor to $0 \%$. The so-adjusted TePaske series is depicted by the solid black in Fig. A.1. It closes much of the 17th century gap between the official production data, and Humboldt's estimate.

The European inflows we calculate based on the American production data should align with the arrival data from Morineau (1985). To calculate European arrivals from American production data we subtract Pacific flows, American retention, and transportation losses. Fig. A.2 displays the resulting inflow series and compares it to Morineau's arrival data. The solid black line depicts our European inflow series, and the gray markers depict Morineau's arrivals. In addition, the dashed gray line depicts European inflows when calculated on the basis of officially registered production only. The figure shows that accounting for unregistered precious metal production is important for bridging the gap between Morineau's arrival series and European inflows as calculated from American production. While the discrepancy between these two series can still be substantial (esp. from 1650 to 1700), this exercise shows that it is possible to substantially narrow down the range of plausible production and inflow values through the cross-validation of different data sources.

Moving from production data to inflow data, Fig. A. 3 compares officially registered precious metal inflows with inflows as reported by the Dutch gazettes (Morineau, 1985). In contrast to the production data, these series include Spanish inflows from Spanish America only; Portuguese gold inflows from America are not contained. Officially registered Spanish inflows come from Hamilton (1934), Fuentes (1980), and García-Baquero (1996), who rely on the official documentation from the Casa de Contratación and individual ship registers.

As is the case with the production data, official inflows fall short of Morineau's unofficial arrival data from the middle of the 17th century onwards, up to the early 18th century. Before that, the official and unofficial data sources are in agreement. After the early 18th century, the official and unofficial data sources converge again (see García-Baquero, 1996, for a detailed comparison).

The shortfall of official inflows vis-à-vis unofficial inflows after 1640 is not solely due to the concomitant increase in unregistered production documented earlier. In addition, it reflects an increase in unregistered transportation, i.e. smuggling across the Atlantic (Mangas, 1989, p.316), and changes in accounting methods for precious metal arrivals (Hamilton, 1934; TePaske, 2010, p.306) that accompanied the shift of colonial trade from Seville to Cádiz. ${ }^{41}$ Thus, while official inflow and production data both suffer from underreporting in the 17 th century, the degree of underreporting appears more manageable in the production data. As a consequence,

was stable. Thus, Brading and Cross (1972) argue that actual Peruvian production did not peak until 1680. At the most fertile Peruvian mines in Potosi, production was taxed at more than twice the rate levied on other mines. Consequently, the incentive to conceal silver production was higher. The illicit production taking place at Zacatecas, Sombrerete, and Potosi, was substantial relative to the total silver production in America. Together these sites accounted for more than $40 \%$ of total official American silver production. The higher unregistered silver production for the second half of the 17th century also squares well with an increase in unregistered silver shipments to Spain during this period (Mangas, 1989, p.316). Both were symptoms of a general weakening of imperial fiscal control (TePaske, 2010, pp.311).

${ }^{41}$ Fuentes (1980), one of the sources for official inflow data, concludes that the official figures for the second half of the 17th century grossly understate actual arrivals. 


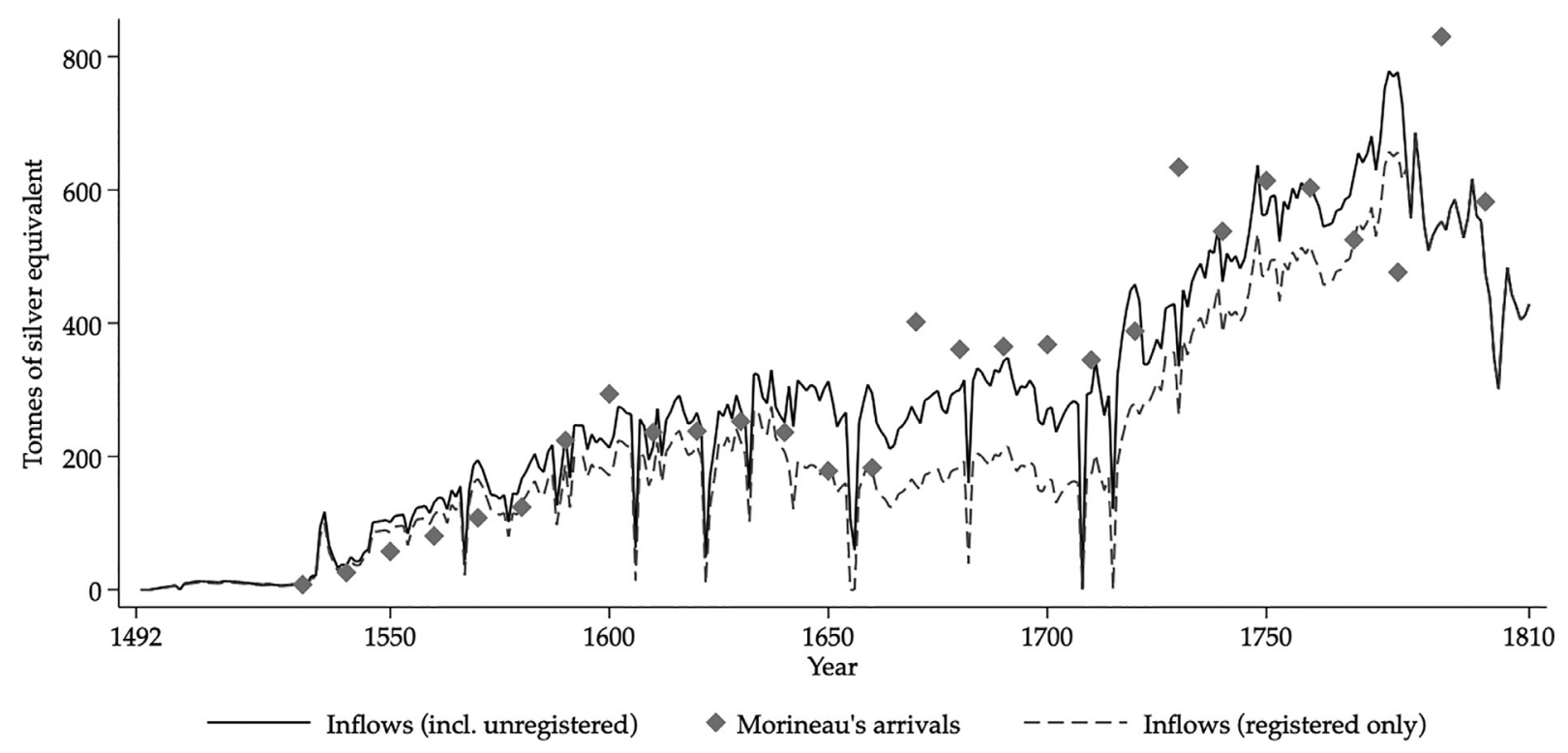

Fig. A.2. American precious metal arrivals in Europe.

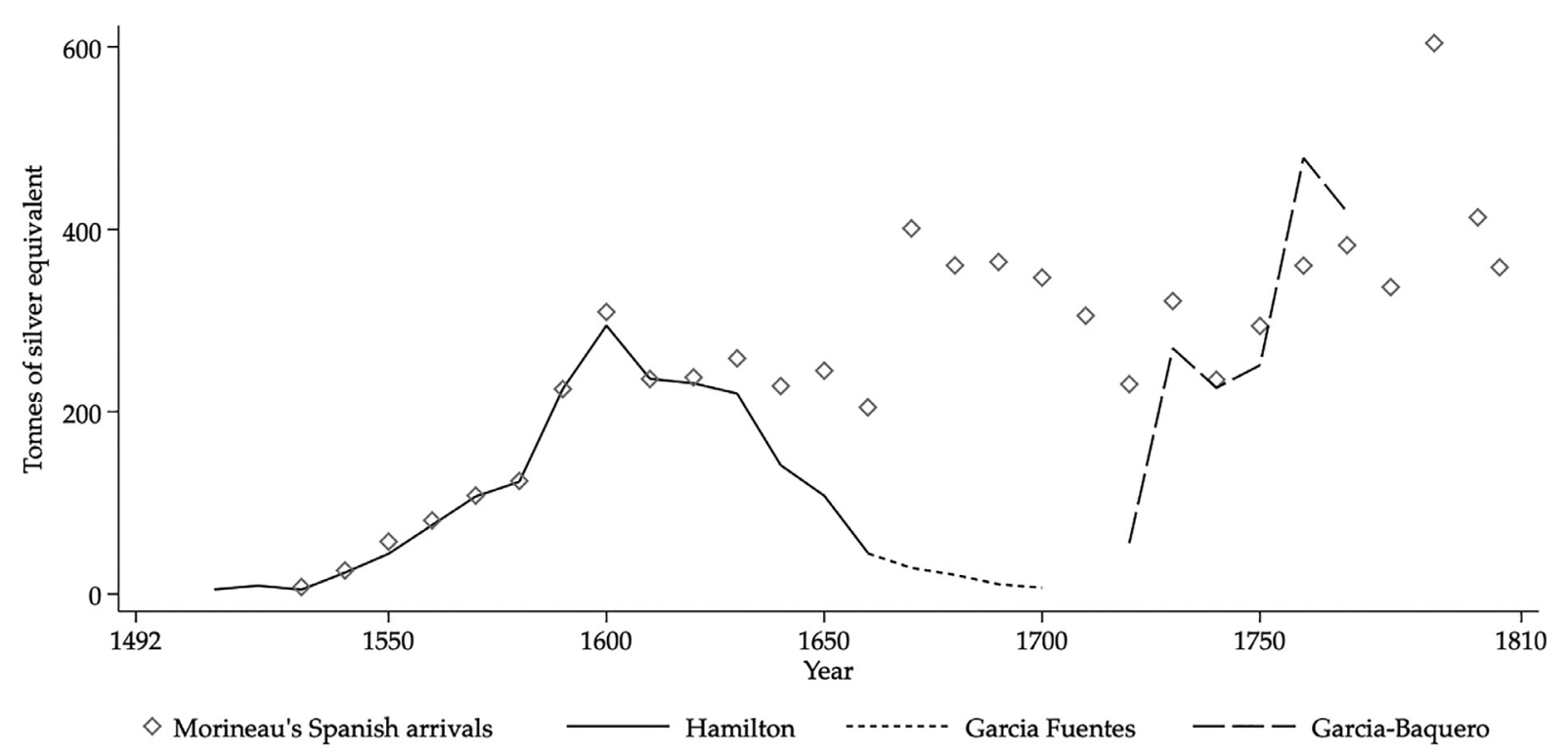

Fig. A.3. Official Spanish inflows versus gazette reports (decade averages) Notes: Black lines: officially registered inflows. Gray diamonds: Spanish American inflows reported in Dutch gazettes.

the official production data can constitute a more reliable basis for estimating American precious metal remittances to Spain than the official Spanish inflow data.

\section{A4. Pacific flows}

Several publications provide comprehensive overviews of early modern precious metal flows across the Pacific (Bonialian, 2012; Flynn and Giráldez, 2017). The amount of silver that was allowed to leave America across this route was capped by the "permiso", which between 1593 and 1776 was only slowly raised from 250,000 pesos to 750,000 pesos. While official "permiso"-values suggest Pacific flows only amounted to a modest fraction of American production, actually shipped amounts routinely exceeded the "permiso" many times over (Chuan, 1969; Flynn and Giraldez, 1995). 
Table A.3

Pacific flows (annual).

\begin{tabular}{|c|c|c|c|}
\hline Years & Source & Silver flow & Notes \\
\hline $1492-1571$ & & $0 \mathrm{~kg}$ & no direct Manila-Acapulco route \\
\hline $1572-1579$ & Legarda (2017) & intrpl & $\begin{array}{l}\text { 1565: discovery of Manila-Acapulco route; } 1572 \\
\text { China connection across Pacific starts in earnest; by } \\
1580 \text { Manila route well established }\end{array}$ \\
\hline $1580-1619$ & $\begin{array}{l}\text { Cross }(1983, \mathrm{p} .412) \text {, Borah } \\
(1954, \mathrm{pp} .88,123)\end{array}$ & $76,680 \mathrm{~kg}$ & $\begin{array}{l}\text { mid-point of } 2 \text { million, } 3 \text { million, and } 4 \text { million peso } \\
\text { estimates }\end{array}$ \\
\hline $1620-1633$ & & intrpl & \\
\hline $1634-1701$ & $\begin{array}{l}\text { Chuan (1997, p.412), Bonialian } \\
\text { (2012, p.44), Schurz (1939, } \\
\text { pp.189ff.) }\end{array}$ & $51,120 \mathrm{~kg}$ & mid-point of $1.5-2.5$ million peso range \\
\hline $1702-1752$ & Bonialian (2012, pp.45ff.) & $76,680 \mathrm{~kg}(74,430 \mathrm{~kg})$ & $\begin{array}{l}\text { mid-point of } 2-4 \text { million peso range (peso silver } \\
\text { content change in 1728) }\end{array}$ \\
\hline 1753-1804 & Schurz (1939, pp.189ff.) & $62,025 \mathrm{~kg}(61,075 \mathrm{~kg})$ & $\begin{array}{l}\text { mid-point of } 2-3 \text { million peso range (peso silver } \\
\text { content change in } 1771 \text { ) }\end{array}$ \\
\hline $1805-1815$ & Legarda (2017) & intrpl & Manila-Acapulco route winds down \\
\hline 1816 & & $0 \mathrm{~kg}$ & Manila-Acapulco route terminates \\
\hline
\end{tabular}

Notes: intrpl - linear interpolation. Silver/peso conversion rates: 1 peso = 25.561 g (1492-1727), 24.809 g (1728-1785), 24.245 g (1786-1810).

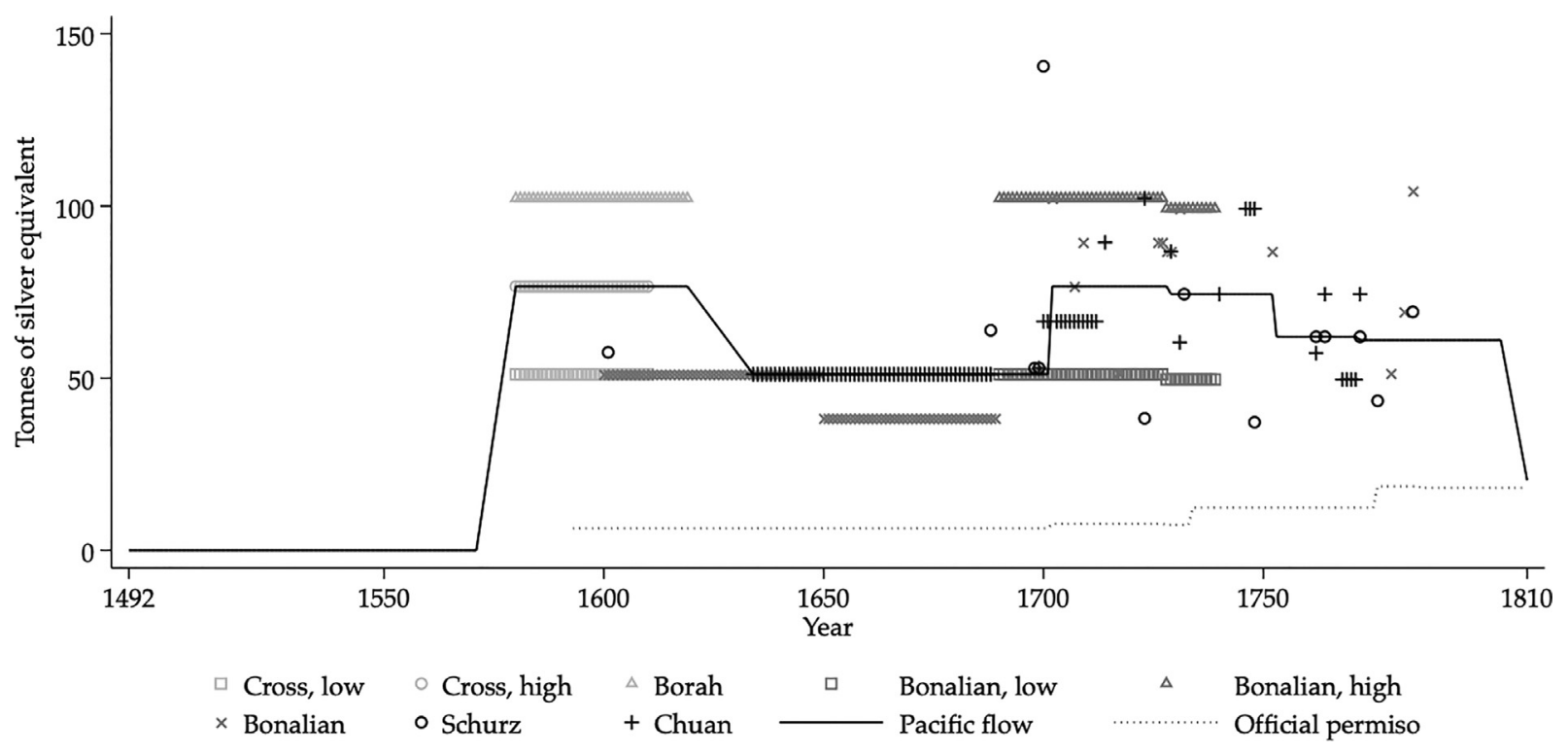

Fig. A.4. Pacific flows.

The clandestine nature of much of the Pacific transfer adds to the uncertainty about the exact quantities involved. However, researchers have attempted to work around this constraint in various ways. The contents of some shipments were revealed after they were captured by privateers. For example, the "Nuestra Señora de Covadonga" alone, captured by Commodore George Anson in 1743 , turned out to carry around 1.5 million pesos; two to three such Pacific shipments per year were not uncommon. For the 17 th century, Chuan (1969) arrives at an estimate of around 2 million pesos per year based on the value of silk that was shipped from China to Manila in expectation of the arriving Spanish silver. This and similarly ingenious use of source material, has led to the accumulation of quantitative data on early modern Pacific flows.

Table A.3 lists mid-point estimates and ranges for Pacific flows across various time periods. The Manila-Acapulco route was discovered in 1565, and terminated in 1816 (Legarda (2017)). In between these dates, flows range from 2 to 4 million pesos in the late 16th and early 17th century, as well as the early 18th century. Flow estimates are somewhat lower in the second halves of the 17 th and 18th centuries, centering around 2 and 2.5 million pesos respectively. Fig. A.4 displays the various flow estimates, together with our preferred mid-point, which is depicted as a solid line. 


\section{A5. Transportation losses}

Table A.4

Atlantic transportation losses: sources.

\begin{tabular}{|c|c|c|c|}
\hline Year & Source & Silver equivalent & Notes \\
\hline 1502 & $\begin{array}{l}\text { Walton (1994, pp.14-15), } \\
\text { Morineau (1985, p.242) }\end{array}$ & $10,955 \mathrm{~kg}$ & 300,000 pesos in gold sunken \\
\hline 1537 & Walton (1994, p.24) & $18,258 \mathrm{~kg}$ & around 500,000 pesos captured \\
\hline 1550 & Potter (1972, pp.215,299) & $8,079 \mathrm{~kg}$ & more than 300,000 pesos sunken \\
\hline 1554 & Walton (1994, p.61) & $73,031 \mathrm{~kg}$ & $\begin{array}{l}\text { almost } 3 \text { million pesos in treasure sunken, about half } \\
\text { salvaged }\end{array}$ \\
\hline 1555 & $\begin{array}{l}\text { Potter (1972, p.160), } \\
\text { Bonifacio (2010) }\end{array}$ & $12,780 \mathrm{~kg}$ & 500,000 pesos sunken \\
\hline 1563 & $\begin{array}{l}\text { Earle (2007, pp.9ff.), } \\
\text { Bonifacio (2010) }\end{array}$ & $24,430 \mathrm{~kg}$ & around 1 million pesos sunken \\
\hline 1567 & Walton $(1994, \mathrm{p} .61)$ & $109,547 \mathrm{~kg}$ & more than 4 million pesos sunken; salvaging failed \\
\hline 1591 & Walton (1994, p.83) & $255,610 \mathrm{~kg}$ & 10 million pesos sunken; about $3 / 4$ salvaged \\
\hline 1605 & Walton (1994, pp.83-84) & $204,488 \mathrm{~kg}$ & 8 million pesos sunken; salvaging failed \\
\hline 1621 & $\operatorname{Marx}(1987$, p.302.) & $382 \mathrm{~kg}$ & $\begin{array}{l}\text { around } 15,000 \text { pesos in treasure sunken; most of it } \\
\text { salvaged }\end{array}$ \\
\hline 1622 & $\begin{array}{l}\text { Potter (1972, pp.215ff.), } \\
\text { Marx (1987, pp.200ff.) }\end{array}$ & $188,951 \mathrm{~kg}$ & $\begin{array}{l}\text { more than } 7 \text { million pesos in treasure sunken; partly } \\
\text { salvaged }\end{array}$ \\
\hline 1623 & $\operatorname{Marx}(1987$, p.202) & $76,345 \mathrm{~kg}$ & about 3 million pesos sunken \\
\hline 1624 & Mangas $(1989$, p.318) & $51,122 \mathrm{~kg}$ & 2 million pesos sunken \\
\hline 1628 & $\begin{array}{l}\text { Potter (1972, p.160), Marx } \\
(1987, \text { p.248) }\end{array}$ & $30,538 \mathrm{~kg}$ & around 1.2 million pesos sunken, largely salvaged \\
\hline 1628 & Venema (2010, p.213) & $80,660 \mathrm{~kg}$ & $\begin{array}{l}177,000 \text { pounds of silver and } 66 \text { pounds of gold } \\
\text { captured }\end{array}$ \\
\hline 1631 & Marx (1987, p.424) & $58,169 \mathrm{~kg}$ & $\begin{array}{l}\text { more than } 2 \text { million pesos sunken; } 1 \text { million pesos } \\
\text { salvaged }\end{array}$ \\
\hline 1631 & Marx (1987, p.249) & $150,241 \mathrm{~kg}$ & $\begin{array}{l}\text { more than } 5.5 \text { million pesos sunken; very little } \\
\text { salvaged }\end{array}$ \\
\hline 1634 & $\begin{array}{l}\text { Sandz and Marx (2001, } \\
\text { p.129) }\end{array}$ & $7,635 \mathrm{~kg}$ & $\begin{array}{l}\text { around } 300,000 \text { pesos in treasure sunken, partly } \\
\text { salvaged }\end{array}$ \\
\hline 1641 & Mangas (1989, p.318) & $76,683 \mathrm{~kg}$ & 3 million pesos sunken \\
\hline 1654 & Earle $(2007, \mathrm{p} .83)$ & $255,610 \mathrm{~kg}$ & 10 million pesos sunken; 3.5 million pesos recovered \\
\hline 1656 & Potter (1972, p.432) & $173,815 \mathrm{~kg}$ & $\begin{array}{l}2 \text { million pesos captured; around } 5 \text { million pesos } \\
\text { sunken }\end{array}$ \\
\hline 1656 & $\begin{array}{l}\text { Walton (1994, pp.128, } \\
\text { 140) }\end{array}$ & $127,805 \mathrm{~kg}$ & 5 million pesos sunken, 2.5 million pesos salvaged \\
\hline 1682 & Bueno (1996, p.84) & $153,366 \mathrm{~kg}$ & 6 million pesos sunken \\
\hline 1698 & www.todoavante.es & $161,540 \mathrm{~kg}$ & $\begin{array}{l}\text { around } 6.5 \text { million pesos sunken, } 6 \text { million pesos } \\
\text { salvaged }\end{array}$ \\
\hline 1702 & Kamen (1966) & $7,350 \mathrm{~kg}$ & $\begin{array}{l}\text { around } 80,000 \text { pesos captured and sunken by British } \\
\text { and Dutch }\end{array}$ \\
\hline 1708 & $\begin{array}{l}\text { Phillips (2007, pp.46,181), } \\
\text { Sedgwick }(1970)^{1}\end{array}$ & $286,283 \mathrm{~kg}$ & 11 million pesos sunken and 200,000 pesos captured \\
\hline 1715 & Marx $(1987, \mathrm{p} .431)$ & $309,972 \mathrm{~kg}$ & 12 million pesos sunken; around 5 million salvaged \\
\hline 1730 & Walton (1994, p.166) & $139,556 \mathrm{~kg}$ & more than 5.5 million pesos sunken; partly salvaged \\
\hline 1733 & Fine $(2006, \mathrm{p} .153)$ & $311,908 \mathrm{~kg}$ & around 12.5 million pesos sunken; almost all salvaged \\
\hline 1750 & $\begin{array}{l}\text { Putley }(2000) \text {, Amrhein } \\
(2007, \text { ch. } 1)^{2}\end{array}$ & $10,321 \mathrm{~kg}$ & $\begin{array}{l}272,000 \text { pesos sunken; } 14,467 \text { pesos salvaged; } \\
144,000 \text { pesos captured }\end{array}$ \\
\hline 1752 & Marx (1987, p.443) & $49,620 \mathrm{~kg}$ & 2 million pesos sunken, mostly salvaged \\
\hline 1753 & Marx (1987, p.443) & $38,134 \mathrm{~kg}$ & 1.5 million pesos sunken \\
\hline 1762 & $\begin{array}{l}\text { Gentleman's and Magazine } \\
\text { (1763, p.528) }\end{array}$ & $62,895 \mathrm{~kg}$ & around 2.5 million pesos captured \\
\hline 1786 & Potter (1972, pp.349ff.) & $185,716 \mathrm{~kg}$ & 7.5 million pesos sunken, mostly salvaged \\
\hline 1800 & Bravo (2010) & $51,264 \mathrm{~kg}$ & around 2 million pesos sunken; partly salvaged \\
\hline 1802 & $\begin{array}{l}\text { Sandz and Marx (2001, } \\
\text { p.218) }\end{array}$ & $13,742 \mathrm{~kg}$ & around 0.5 million pesos sunken \\
\hline 1804 & Cobbett (1804, p.663) & $113,084 \mathrm{~kg}$ & 1.5 million pesos sunken; 3 million pesos captured \\
\hline
\end{tabular}

Notes: 1 URL: http://www.historyofparliamentonline.org/volume/1715-1754/member/wager-sir-charles-1666-1743\#footnoteref3_g4iwhgx.

${ }^{2}$ Loss associated with the ship "El Salvador" corrected to 240,000 pesos; correction confirmed with the author. Where sources refer to officially registered silver transports only, we add an estimate of the smuggled silver as follows: $30 \%$ for the 16th century (average from Morineau, 1985, p.242), $67 \%$ for the 17 th century from Mangas (1989, p.316) or Morineau (1985, p.242), and 46\% for the 18th century (including the years up to 1810) from Morineau (1985, p.375). Silver/peso conversion rates: 1 peso $=25.561 \mathrm{~g}$ (1492-1727), $24.809 \mathrm{~g}$ (1728-1785), 24.245 g (1786-1810). 


\section{A6. Outflows}

This section gives an overview of the Spanish outflow data. Table A.5 shows Spanish money outflows as a fraction of inflows from Spanish America - the Spanish outflow rate. Fig. A.5 displays the linearly interpolated series together with the individual observations from Attman and Walton.

Table A.5

Spanish outflows (\% of American inflows).

\begin{tabular}{|c|c|c|c|}
\hline Years & Source & Outflow rate & Notes \\
\hline $1492-1588$ & & $91 \%$ & $\begin{array}{l}\text { Representative outflow ratio for normal } \\
\text { periods in } 17 \text { th and } 18 \text { th centuries }\end{array}$ \\
\hline 1589-1599 & Walton $(1994, \mathrm{p} .86)^{a}$ & $107 \%$ & Height of the Dutch War for Independence \\
\hline 1600 & & $91 \%$ & $\begin{array}{l}\text { Representative outflow ratio for normal } \\
\text { periods in } 17 \text { th century }\end{array}$ \\
\hline $1601-1640$ & & intrpl & \\
\hline $1641-1642$ & $\begin{array}{l}\text { Attman }(1986, \text { p.36) })^{a} \\
\text { Walton }(1994, \text { pp.86,145) }\end{array}$ & $91 \%$ & \\
\hline $1643-1667$ & & intrpl & \\
\hline $1668-1670$ & Attman (1986, p.40) & $92 \%$ & \\
\hline 1671-1699 & & intrpl & \\
\hline 1700 & Attman (1986, p.30) & $100 \%$ & \\
\hline $1701-1713$ & $\begin{array}{l}\text { Attman (1986, p.30) \& Walton } \\
(1994, \text { p.156) }\end{array}$ & $106 \%$ & War of Spanish Succession \\
\hline $1714-1750$ & Attman (1986, p.30) & $100 \%$ & \\
\hline $1751-1769$ & & intrpl & \\
\hline $1770-1779$ & Walton (1994, p.181) & $100 \%$ & \\
\hline $1780-1789$ & Attman (1986, pp.30,32) & $91.5 \%$ & \\
\hline $1790-1810$ & & $91.5 \%$ & continuation/extrapolation \\
\hline
\end{tabular}

Notes: intrpl - linear interpolation. ${ }^{a}$ Source states an absolute Spanish outflow value without accompanying inflow. Where sources state an absolute Spanish outflow value without accompanying inflow, we divided this value by our inflow series $\left(i n_{k}^{A M \rightarrow E S P}\right.$ from Eq. 2).

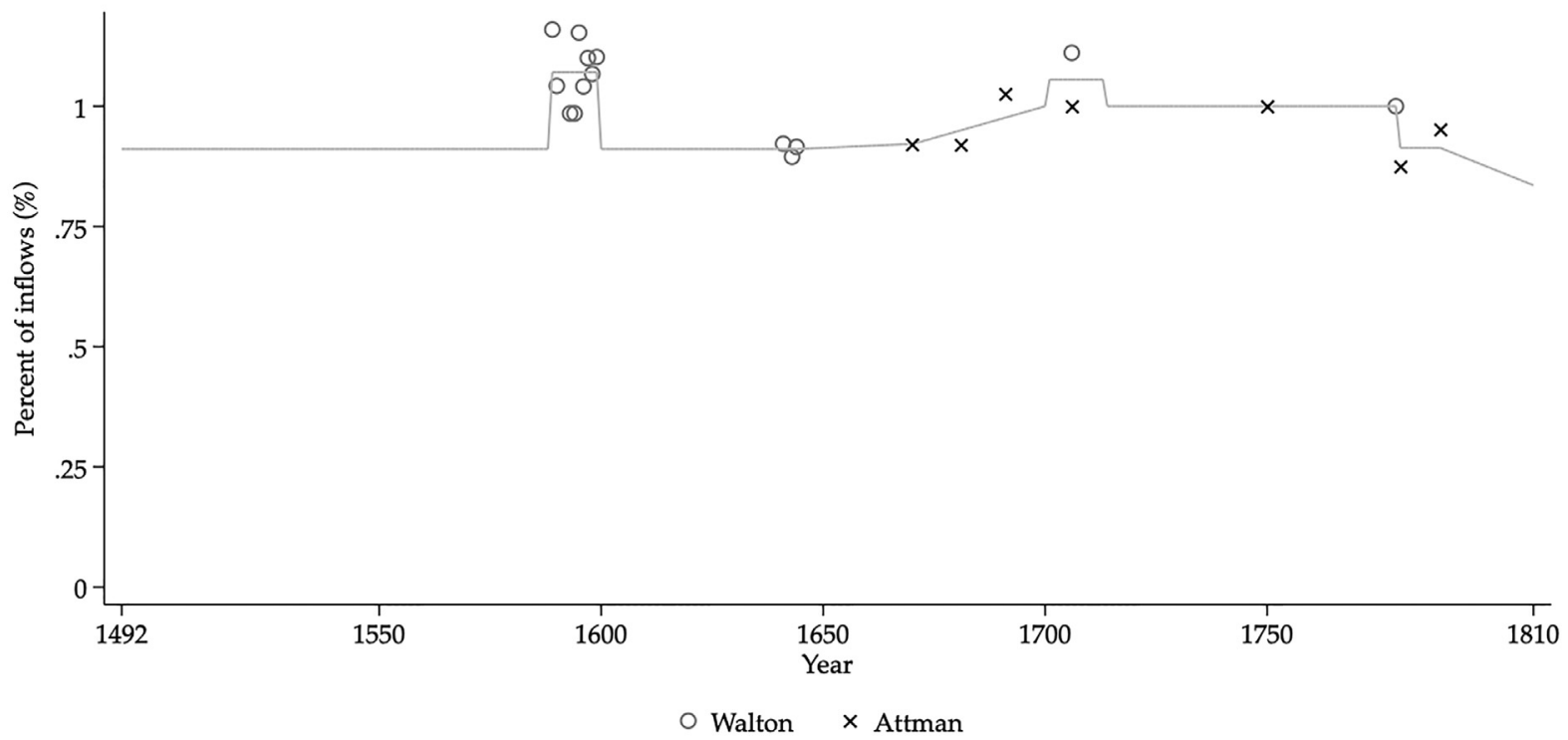

Fig. A.5. Spanish outflows (\% of American inflows).

\section{Appendix B. Alternative money stock estimates}

In this section we briefly introduce two alternative money stock measures, that act as a robustness check for our baseline estimate. The first alternative estimate is the European in/out based estimate, for which we calculate the Spanish money stock as a share of the European money stock. We do so in two steps. First, we calculate the European precious metal stock by combining an estimate of the initial European stock in 1492 with data on Europe's precious metal inflows, outflows, and production. Second, we calculate the Spanish share of European precious metals after 1492 according to Spain's average share of European GDP. This allows us to 


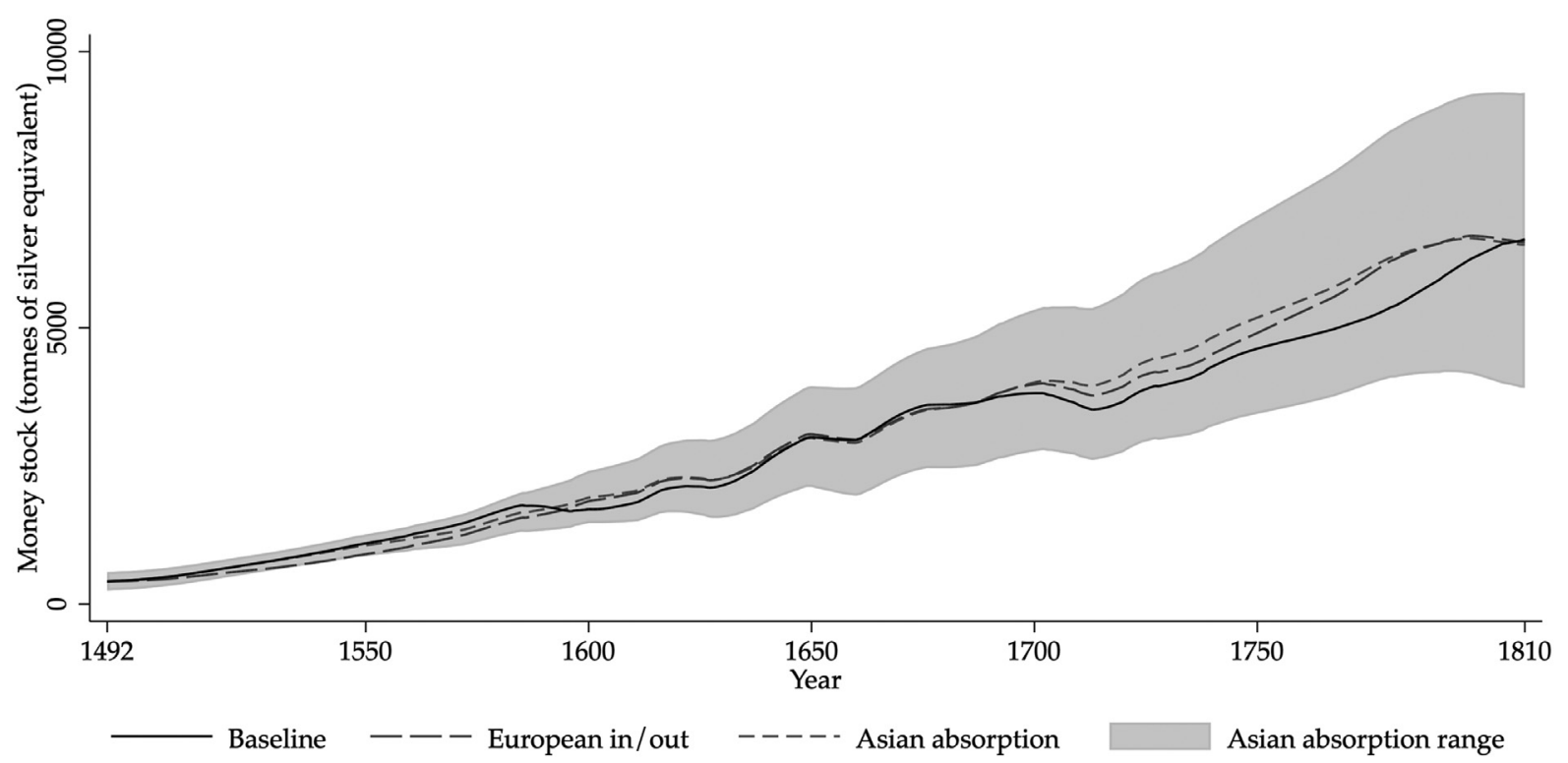

Fig. B.1. Money stock measures (11-year moving averages).

replace the sparse Spanish outflow data with the more abundant European outflow data. The European in/out based estimate of the Spanish money stock is depicted as the dashed gray line in Fig. B.1. Overall, the European in/out based estimate exhibits trends and low frequency variations that are similar to the baseline estimate.

The second alternative estimate is the Asian absorption estimate. In contrast to the previous two money stock estimates, the Asian absorption estimate dispenses with the need for data on Pacific precious metal flows, as well as Spanish and European outflows. Instead, it relies on an estimate of the quantity of precious metals that eventually wound up in Asia. The latter is often expressed as a fraction of the American precious metal production - the so-called Asian absorption rate. Based on this absorption rate, we obtain an estimate of the European money stock. We then proceed in the same way as for the European in/out based estimate.

Estimates of the Asian absorption center around $50 \% .{ }^{42}$ To reflect the uncertainty around these estimates, we calculate a range of stock estimates assuming the Asian absorption rate was at least $33 \%$, but no more than $66 \%$. The result is shown as the gray area in Fig. B.1. ${ }^{43}$ The short-dashed gray line indicates the center of this range, which corresponds to a $50 \%$ Asian absorption rate.

Reassuringly, the European in/out based estimate, as well as the Asian absorption estimate are very similar to the baseline estimate. The largest discrepancy occurs in the 18th century, where the Spanish outflow data suggests a hemorrhaging of Spanish silver that is not captured by the two alternative estimates. Unsurprisingly, the two alternative estimates also miss the Spain-specific increase in money outflows during the Dutch War of Independence and the War of Spanish Succession. The following sections describe the construction of the European in/out and Asian absorption estimates in greater detail.

\section{B1. European in/out estimate}

Initial stock

For the initial European precious metal stock estimate we rely on the same sources as for the baseline series. If we take the European share of the Velde and Weber (2000b) estimate of the global precious metal stock according to the European-to-World GDP ratio around 1500 (Bolt et al., 2018) $(\approx 23 \%)$ we obtain a value of 1510 tonnes of silver equivalents - 823 tonnes of silver and 68 tonnes of gold. ${ }^{44}$ This constitutes the lower bound of our initial stock range for Europe. The highest plausible initial value is 3749 tonnes of silver equivalents (Jacob, 1831). The mid-point of the 1510 to 3749 ton range - 2630 tonnes - serves as our initial European stock estimate.

\footnotetext{
42 Irigoin (2009, p.207) provides an overview of references in this regard.

${ }^{43}$ The $33 \%$ absorption rate scenario starts with the upper bound initial precious metal value, whereas the $66 \%$ absorption rate starts with the lower bound initial value.

44 The European GDP figure includes Belgium, Finland, France, Germany, Greece, Italy, the Netherlands, Poland, Portugal, Spain, Sweden, Switzerland, and England. We linearly interpolate the underlying population and real purchasing power adjusted per capita GDP series from Bolt et al. (2018).
} 
Inflows

The European inflow measure differs from the Spanish one in the following ways: First, to arrive at total European precious metal inflows, we add non-Spanish European precious metal arrivals, $i n_{k}^{R O W \rightarrow E U}$, and the complete European precious metal production, $\operatorname{prod}_{k}^{E U}$, instead of only a fraction. Second, we need to replace the Spanish transport loss measure, $\operatorname{loss}_{k}$, with the European transport loss measure, $\operatorname{loss}_{k}^{E U}$. The difference between the two equals piracy losses, pir $_{k}$, which constituted only a redistribution of precious metal inflows within Europe - away from Spain to the pirates' home country. Finally, we remove the diffusion term, $d i f f_{k}$, from the European inflow equation. ${ }^{45}$ The resulting European precious metal inflow is

$$
\begin{aligned}
\operatorname{in}_{k}^{E U} & =\underbrace{\operatorname{prod}_{k-1}^{E S P}\left(1-\operatorname{retent}_{k}\right)(1-0.52 \%)-\text { pacific }_{k}-\operatorname{loss}_{k}^{E U}+\operatorname{salv}_{k-1}}_{\equiv i n_{k}^{A M \rightarrow E U}} \\
& +\left(\operatorname{prod}_{k}^{E U}+i n_{k}^{R O W \rightarrow E U}\right)(1-0.52 \%),
\end{aligned}
$$

where $\operatorname{loss} s_{k}^{E U}=l o s s_{k}-p i r_{k}$, and all other terms are defined as for the baseline estimate (see Eq. 2).

\section{Outflows}

We combine the European inflow data with European outflow data from Attman (1986) and de Vries (2003). In particular, we use Attman's estimates for precious metal flows across the Baltic and Levant, and de Vries' revision of direct flows to East Asia via the Cape route. This outflow data consists of 25-year averages. It is thus available at a higher frequency than the Spanish outflow data that we use for the baseline estimate.

\section{Money stock}

Based on the initial European stock and the European in- and outflow data we calculate the European precious metal stock, $M_{t}^{E U}$, according to Eq. 1. We then calculate an intermediary measure for the Spanish money supply according to Spain's share of European GDP:

$$
\tilde{M}_{t}^{\text {Europeanin/out }}=\chi^{E U} M_{t}^{E U}
$$

where $\chi^{E U}$ denotes Spain's average share of European GDP over the period 1492 to 1810.

We need to make some Spain-specific adjustments to the intermediary stock measure, $\tilde{M}_{t}^{\text {Europeanin/out }}$, to arrive at the final European in/out based measure for the Spanish money supply. First, we subtract piracy related money losses, pir $_{k}$, because they constituted losses to the Spanish money stock that are not reflected in the European stock measure, $M_{t}^{E U}$. Second, we correct for the rescaling of the non-piracy related transportation losses in Eq. B.2, recognizing that the entire loss was initially born by Spain (Nogues-Marco, 2011, p.6). The same logic applies to salvaged precious metals. These two adjustments are summarized in the following term:

$$
a d j_{k}^{\text {inflow }, E U}=- \text { pir }_{k}-\left(\operatorname{loss}_{k}^{E U}-\operatorname{salv}_{k-1}\right)\left(1-\chi^{E U}\right) \text {. }
$$

Next, we account for the diffusion of Atlantic transportation losses over time. In contrast to the baseline money supply estimate, however, we only need to adjust for the money loss diffusion within Europe. The European diffusion to the rest of the world is already accounted for in European outflows. Accordingly, we assume that, in the long-run, Spain bore precious metal losses in proportion to its European GDP share. We apply the same linear diffusion process as for the baseline estimate to transition from the initial Spanish money loss value to the long-run value.

The European in/out based estimate of the Spanish money stock, $M_{t}^{\text {Europeanin/out }}$, is obtained by subtracting the cumulative sum of the above two adjustments from the intermediary measure, taking into account that the adjustment terms need to be subjected to the same annual depreciation rate:

$$
M_{t}^{\text {Europeanin } / \text { out }}=\tilde{M}_{t}^{\text {Europeanin } / \text { out }}+\sum_{k=1493}^{t}\left(\operatorname{adj} j_{k}^{\text {inflow }, E U}+\operatorname{diff} f_{k}^{E U}\right)(1-0.24 \%)^{t-k}
$$

\section{B2. Asian absorption estimate}

\section{Initial stock}

The Asian absorption estimate starts from the same initial value range as the European in/out based estimate: The low value of 1510 tonnes of silver equivalent initiates the lower bound of the Asian absorption range estimate. The lower bound Asian absorption estimate is then calculated based on a high Asian absorption rate of 66\%. The high value of 3749 tonnes initiates the upper bound estimate, which uses the low Asian absorption rate of 33\%. Finally, the mid-point Asian absorption estimate of the Spanish money stock starts at the mid-point of the 1510 to 3749 t range, i.e. 2630 tonnes.

\footnotetext{
45 In contrast to the sparse annual data on Spanish outflows, the European outflow data in principle already reflects the diffusion of Atlantic transport losses through a reduction in European precious metal outflows. In practice, however, the diffusion of Atlantic transportation losses was too small compared to the European stock, and too small compared to the measurement uncertainty in European outflows, to significantly affect the European stock estimate.
} 


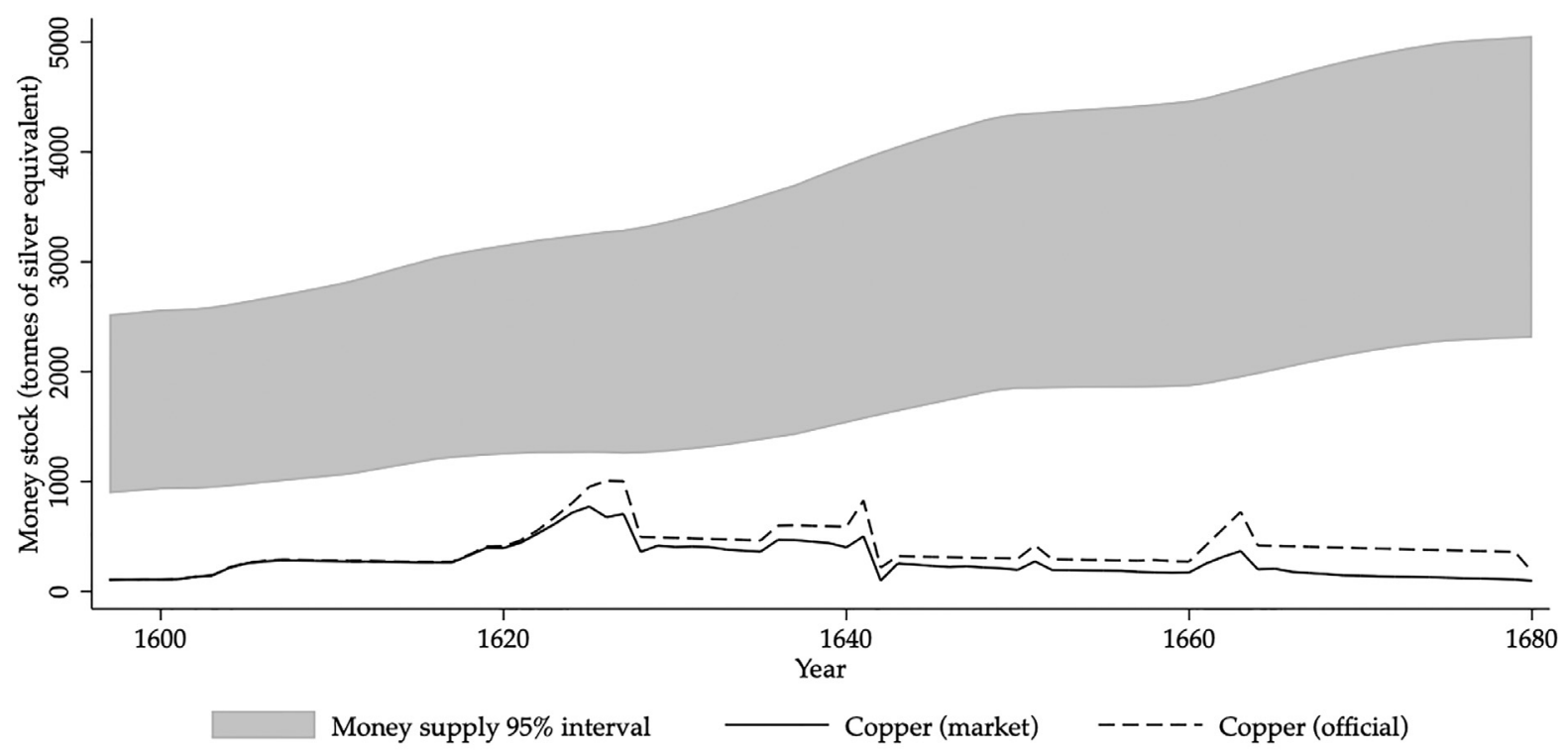

Fig. B.2. Copper money.

\section{Inflows and outflows}

The Asian absorption estimate replaces the Pacific flow data and the European outflow data with an estimate of the quantity of precious metals that eventually wound up in Asia, expressed as a fraction of the American precious metal production. European net-inflows thus become

$$
\begin{aligned}
\operatorname{in}_{k}^{E U}-\text { out }_{k}^{E U} & =\underbrace{\operatorname{prod}_{k-1}^{A M}\left(1-\operatorname{retent}_{k}\right)(1-0.52 \%)-\operatorname{loss}_{k}^{E U}+\operatorname{salv}_{k-1}}_{i n_{k}^{A M \rightarrow E U}} \\
& \left.+\operatorname{prod}_{t}^{E U}+i n_{k}^{A F R \rightarrow E U}\right)(1-0.52 \%) \\
& -\operatorname{prod}_{k-1}^{A M}(1-0.52 \%) a b s o r b^{\text {asia }}
\end{aligned}
$$

where $\operatorname{prod}_{k-1}^{A M}$ is the total American production (i.e. Portuguese American and Spanish American), $i n_{k}^{A F R \rightarrow E U}$ denotes gold inflows from Africa, and absorb ${ }^{a s i a}$ is the Asian absorption rate. All other terms are defined as before.

\section{Money stock}

We use the net inflow series B.5 to first calculate the European money stock, $M_{t}^{E U, A s i a n a b s o r p t i o n}$. Based on this European stock we calculate an intermediate Asian absorption estimate of the Spanish money stock, $\tilde{M}_{t}^{\text {Asianabsorption }}$, according to Spain's European GDP share. To arrive at the final Asian absorption estimate for Spain, $M_{t}^{\text {Asianabsorption }}$, the intermediary measure undergoes the same set adjustments as the intermediary European in/out measure:

$$
M_{t}^{\text {Asianabsorption }}=\tilde{M}_{t}^{\text {Asianabsorption }}+\sum_{k=1493}^{t}\left(a d j_{k}^{\text {inflow } E U}+d i f f_{k}^{E U}\right)(1-0.24 \%)^{t-k} .
$$

\section{B3. Copper money}

Starting in the late 16th century, fiscal pressures arising from persistent warfare led to the issuance of increasing amounts of copper money. Fig. B.2 depicts the accumulating copper money stock from Velde and Weber (2000a) converted into silver equivalents. The solid line uses the market exchange rate between copper and silver coins for this conversion, the dashed line uses the official face value ratio. The gray area depicts the centered 11-year moving average of the $95 \%$ probability region for the baseline money supply estimate. $^{46}$

\footnotetext{
46 The original data from Velde and Weber (2000a), Table 6, Column: "total”) is provided in units of account (Ducats à 375 Maravedís de vellón). Maravedís de vellón can be converted into tonnes of silver equivalent according to two different conversion rates. First, according to Spain's official conversion rate of $25.561 \mathrm{~g}$ of silver per 272 Maravedí. Using this official conversion rate, however, neglects the fact that, in the market, copper coins traded at a discount vis-à-vis silver coins of identical Maravedí face value. This discount reflected the extent to which market participants were reluctant to accept copper coins for payment. Converting Maravedí de vellón into silver equivalent based on market rates thus results in a lower silver value for the same copper money stock.
} 
After 1617, when public authorities sanctioned the minting of copper coins, the copper money stock rapidly built up to around half of the value of the gold and silver money supply. Over the subsequent decades, copper money lost its importance and after 1664 it became largely inconsequential as a consequence of the decision to halt copper minting. While copper money existed before and after this period, its role was much diminished outside of the early 17th century (Velde and Weber, 2000a).

According to Hamilton (1934) and Velde and Weber (2000b) the rise of copper money in the early 1600s primarily altered the composition of the Spanish money stock, not its level. This is because copper coins displaced gold and silver coins, that were driven out of circulation. However, temporary over- or underreaction in short-term gold and silver outflows cannot be ruled out. For example, more silver may have left Spain in 1625-27 and 1640-42 when severe flights to silver led to sudden spikes in the market exchange rate between copper and silver coins. More generally, the minting of copper coins adds to the uncertainty about the Spanish money stock for this period. As a consequence, the 95\% probability interval depicted in Fig. B.2 may be considered too narrow during the first half of the 17th century.

\section{Appendix C. Additional results}

\section{C1. Robustness to initial stock level}

Owing to the large influx of precious metals over the early modern period, the initial stock choice for 1492 has only a small influence on the final stock level in 1810. For the decomposition analysis, however, the initial stock is more influential. A doubling in the initial stock implies almost a halving of subsequent money growth. For large enough initial stock values, velocity changes will replace money changes as the most influential accounting item behind Spain's early modern price level rise. In this section we calculate the initial stock level at which this change in results occurs.

To find the threshold initial stock level at which money growth ceases to be the main factor behind Spain's early modern price level rise, we conduct a grid search over initial stock levels at $25 \mathrm{t}$ intervals. For each initial money stock level we recalculate the percentage contributions of money growth, velocity growth, and real output growth. We find that the velocity growth contribution draws even with money growth at an initial money stock level of 2300 tonnes, at which both items account for 36\% of Spain's price level rise. 2300 tonnes is around 5.8 times our baseline initial estimate of 396 tonnes. Beyond an initial stock value of 2300 tonnes, the contribution of a more than 3.9 fold increase in velocity begins to dominate the contribution of a less than 3.9 fold increase in the money stock.

In Section A.2 we have argued that among existing initial stock estimates for Europe all well-grounded ones fall into the 1,5193,749 range. Using Spain's European GDP share of around 15\% an initial stock of 2300 tonnes for Spain implies an initial European stock of 15,333 tonnes. While we cannot exclude the possibility that future research comes up with a convincing argument for such a high initial European stock value, 15,333 tonnes sets a high bar for overturning the decomposition finding that money growth was the most important factor behind Spain's early modern price level rise.

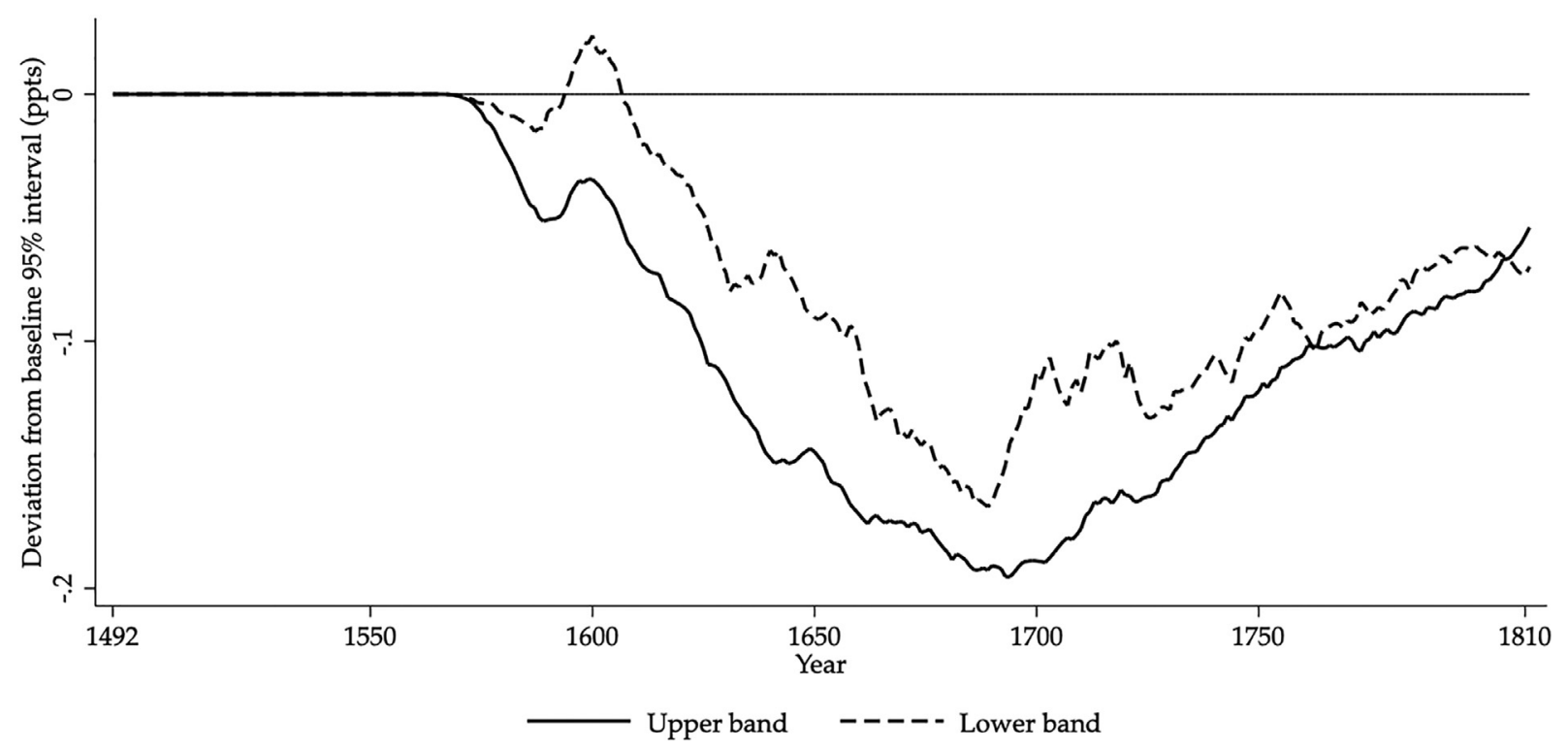

Fig. C.1. Percentage point deviation of $95 \%$ intervals with and without covariances Notes: Distributions based on 10,000 draws from the input variable distribution. Centered 11-year moving average, neglecting missing observations at the borders. 


\section{C2. Probability interval and covariances}

Our baseline probability distribution for the Spanish money stock is based on independent random draws from each input variable's distribution. This section examines the role of dependencies across input variables. After a short description of what we deem to be the most important dependencies, we compare the baseline $95 \%$ probability interval with the $95 \%$ probability interval that originates from a stochastic simulation that takes cross-input variable dependencies into account.

In principle, co-moving input variables can inflate or deflate the uncertainty surrounding the money stock estimate. In our application, however, the most salient dependencies appear to work in favor of a narrower probability distribution for the Spanish money stock. The two input variable covariances we deem most important are i) the covariance between American production volumes and Pacific flows, and ii) the covariance between Spanish inflows and Spanish outflows.

First, consider the covariance between American production volumes and Pacific flows, and how it affects the probability distribution for Spain's money stock. It is plausible to assume that larger American production volumes allowed for larger Pacific flows. A positive covariance between the two variables dampens the volatility of their difference - in this case the amount of precious metals arriving in Spain. Less uncertainty about Spanish inflows in turn translates into less uncertainty about the Spanish money stock.

Second, Spanish outflows can be expected to co-move with Spanish inflows: the more money arrives in Spain, the more will leave, e.g. through an increase in Spanish goods imports from the rest of Europe. What does this imply for the uncertainty surrounding the Spanish money stock estimate? The positive covariance between Spanish in- and outflows dampens the variation in the Spanish money stock. ${ }^{47}$ Note that because Spanish outflows are calculated as a fraction of Spanish inflows the baseline analysis already implicitly takes this dependency into account. ${ }^{48}$

Next, we incorporate covariances i) and ii) into a stochastic simulation to generate probability intervals that account for both dependencies. The sample correlation between American production and Pacific flows is 0.25 between 1572 and 1720 - the year when the Pacific route opened and the year when its eventual decline set in. After 1720 Pacific flows decouple from American production volumes. To account for this dependency, we assume that between 1572 and 1720 American production and Pacific flows co-move according to their sample covariance. The covariance between Spanish inflows and outflows is already reflected in the baseline analysis, because outflows are calculated as a fraction of inflows. Although the Spanish outflow rate out ${ }_{k}^{E S P}$ is drawn independently as specified in Table A.1, the resulting outflow series already exhibits the desired covariance with inflows.

Fig. C.1 displays the percentage point deviation between the baseline $95 \%$ probability interval and the $95 \%$ interval with added covariance. The difference between the two probability intervals is small. The upper band with added covariance lies at most 0.2 percentage points below the baseline upper band. The lower band with added covariance also lies lower, but less so than the upper band. As a consequence, the $95 \%$ probability band with added covariance is slightly narrower after 1572 , when the Pacific flow starts.

\section{C3. Subsample decomposition results}

While money growth was the dominant influence on the Spanish price level over the period from 1492 to 1810 as a whole, this does not necessarily hold for all sub-periods. The price history of early modern Spain can be separated into three distinct phases: The price revolution (lasting up to 1650), the deflationary period (from 1651 to 1750), and a period of reflation (after 1750). Table C.1, panels B to D shows the decomposition results for these three sub-periods. For reference, panel A repeats the full sample results from the main text.

Panel B shows that money growth accounts for around three quarters of the almost four-fold increase in prices between 1492 and 1650 - the so-called price revolution. During the same period, GDP growth and a decreasing velocity drove a wedge between the 7-fold increase in money supply and the increase in prices.

Panel $\mathrm{C}$ shows that declining velocity played an important role in the ensuing deflation between 1651 and 1750 . It accounts for $40 \%$ of the price decline. GDP growth of around $40 \%$ also took pressure off prices. As a consequence, a $55 \%$ increase in money supply did not translate into inflation during this period. The decomposition result for the post-1650 deflation is thus consistent with a velocity-based explanation (Goldstone, 1991). Finally, panel D displays the decomposition results for the period of reflation, 1751 to 1810 . During this period prices rose by almost $200 \%$. Partly this is accounted for by a $42 \%$ increase in the money supply. Rising

\footnotetext{
47 The covariance between Spanish in- and outflows is actually a summary covariance, because the inflow series incorporates the random draws from most other input variables (see Eq. 2 in the main text). Accounting for the dependency between Spanish in- and outflows thus constitutes a partial remedy for inaccurate covariance assumptions that enter the construction of the Spanish inflow series. For example, excessive Spanish inflows (e.g. brought about by a disregard of the covariance between American production and Pacific flows) can be partially remedied by accounting for a positive covariance between Spanish in- and outflows. This is because when excessive Spanish inflows are offset by excessive Spanish outflows, the Spanish money supply estimate becomes less volatile than it would be otherwise.

${ }^{48}$ How about other input variable covariances? The logic that applies to Spanish in- and outflows in principle also applies to European in- and outflows. But European in- and outflows play only a minor role in the baseline estimate of Spain's money stock (see the last term in Eq. 2 in the main text). We thus disregard this dependency. The same holds for the plausible dependencies between European outflows and other input variables, such as European production, and African arrivals. Do there exist potentially important dependencies that could increase the $95 \%$ probability interval of the Spanish money stock estimate? For example, a positive correlation between Spanish outflows and Pacific flows, or a negative correlation between American production and Spanish outflows. The practical relevance for such dependencies is less evident than in the previously discussed cases i) and ii). We therefore also do not consider them.
} 
Table C.1

Equation of exchange decomposition - Sub-periods.

\begin{tabular}{|c|c|c|c|c|}
\hline Variable $i$ & Prices $(P)$ & Money $(M)$ & Velocity $(V)$ & Real GDP $(Y)$ \\
\hline & \multicolumn{4}{|c|}{ A: 1492-1810: Full sample } \\
\hline Actual change & x 4.95 & x 15.67 & x 0.89 & x 2.80 \\
\hline \multirow[t]{3}{*}{ Importance $I(\cdot)$} & & $70 \%$ & $3 \%$ & $\mathbf{2 6 \%}$ \\
\hline & & {$[62 \%, 71 \%]$} & {$[0 \%, 14 \%]$} & {$[21 \%, 30 \%]$} \\
\hline & & \multicolumn{3}{|c|}{ B: $1492-1650:$ Price revolution } \\
\hline Actual change & x 3.87 & x 7.09 & x 0.76 & x 1.38 \\
\hline \multirow[t]{3}{*}{ Importance $I(\cdot)$} & & $76 \%$ & $11 \%$ & $13 \%$ \\
\hline & & {$[66 \%, 82 \%]$} & {$[1 \%, 24 \%]$} & {$[9 \%, 20 \%]$} \\
\hline & \multicolumn{4}{|c|}{ C: 1651-1750: Deflation } \\
\hline Actual change & x 0.65 & x 1.55 & x 0.60 & x 1.41 \\
\hline \multirow[t]{3}{*}{ Importance $I(\cdot)$} & & $34 \%$ & $40 \%$ & $27 \%$ \\
\hline & & {$[24 \%, 38 \%]$} & {$[34 \%, 42 \%]$} & {$[20 \%, 42 \%]$} \\
\hline & \multicolumn{4}{|c|}{ D: 1751-1810: Reflation } \\
\hline Actual change & x 1.94 & x 1.42 & x 1.89 & x 1.38 \\
\hline \multirow[t]{2}{*}{ Importance $I(\cdot)$} & & $27 \%$ & $49 \%$ & $25 \%$ \\
\hline & & {$[13 \%, 42 \%]$} & {$[33 \%, 61 \%]$} & {$[24 \%, 27 \%]$} \\
\hline
\end{tabular}

Notes: \% decomposition based on log changes. The percentage contributions may not add up to exactly $100 \%$ due to rounding. $95 \%$ probability interval in brackets.

velocity, however, plays a larger role. It explains $49 \%$ of the reflation. Accelerating GDP growth towards the end of the early modern period counteracted the dual inflationary pressures arising from a rising money supply and a resurging velocity.

\section{Appendix D. Money supply tables}

Table D.1

Baseline money supply estimate (tonnes; centered 11-year moving average).

\begin{tabular}{|c|c|c|c|c|c|c|c|c|c|c|c|c|c|}
\hline 1492 & 411 & 1543 & 985 & 1593 & 1,722 & 1643 & 2,749 & 1693 & 3,761 & 1743 & 4,418 & 1793 & 5,997 \\
\hline 1493 & 414 & 1544 & 1,002 & 1594 & 1,703 & 1644 & 2,798 & 1694 & 3,775 & 1744 & 4,454 & 1794 & 6,050 \\
\hline 1494 & 418 & 1545 & 1,019 & 1595 & 1,688 & 1645 & 2,844 & 1695 & 3,788 & 1745 & 4,488 & 1795 & 6,104 \\
\hline 1495 & 421 & 1546 & 1,036 & 1596 & 1,676 & 1646 & 2,889 & 1696 & 3,799 & 1746 & 4,521 & 1796 & 6,154 \\
\hline 1496 & 425 & 1547 & 1,053 & 1597 & 1,693 & 1647 & 2,931 & 1697 & 3,806 & 1747 & 4,548 & 1797 & 6,205 \\
\hline 1497 & 427 & 1548 & 1,072 & 1598 & 1,696 & 1648 & 2,977 & 1698 & 3,812 & 1748 & 4,575 & 1798 & 6,253 \\
\hline 1498 & 434 & 1549 & 1,083 & 1599 & 1,704 & 1649 & 3,013 & 1699 & 3,815 & 1749 & 4,600 & 1799 & 6,291 \\
\hline 1499 & 440 & 1550 & 1,097 & 1600 & 1,717 & 1650 & 3,024 & 1700 & 3,817 & 1750 & 4,624 & 1800 & 6,329 \\
\hline 1500 & 447 & 1551 & 1,112 & 1601 & 1,714 & 1651 & 3,015 & 1701 & 3,818 & 1751 & 4,646 & 1801 & 6,368 \\
\hline 1501 & 454 & 1552 & 1,126 & 1602 & 1,716 & 1652 & 3,010 & 1702 & 3,817 & 1752 & 4,668 & 1802 & 6,406 \\
\hline 1502 & 461 & 1553 & 1,140 & 1603 & 1,721 & 1653 & 3,003 & 1703 & 3,789 & 1753 & 4,689 & 1803 & 6,444 \\
\hline 1503 & 469 & 1554 & 1,154 & 1604 & 1,732 & 1654 & 2,995 & 1704 & 3,776 & 1754 & 4,709 & 1804 & 6,482 \\
\hline 1504 & 478 & 1555 & 1,168 & 1605 & 1,745 & 1655 & 2,987 & 1705 & 3,748 & 1755 & 4,730 & 1805 & 6,521 \\
\hline 1505 & 486 & 1556 & 1,184 & 1606 & 1,759 & 1656 & 2,979 & 1706 & 3,720 & 1756 & 4,751 & 1806 & 6,534 \\
\hline 1506 & 496 & 1557 & 1,199 & 1607 & 1,774 & 1657 & 2,973 & 1707 & 3,693 & 1757 & 4,767 & 1807 & 6,551 \\
\hline 1507 & 505 & 1558 & 1,213 & 1608 & 1,790 & 1658 & 2,970 & 1708 & 3,667 & 1758 & 4,787 & 1808 & 6,564 \\
\hline 1508 & 516 & 1559 & 1,228 & 1609 & 1,806 & 1659 & 2,969 & 1709 & 3,645 & 1759 & 4,807 & 1809 & 6,578 \\
\hline 1509 & 527 & 1560 & 1,250 & 1610 & 1,825 & 1660 & 2,971 & 1710 & 3,599 & 1760 & 4,827 & 1810 & 6,607 \\
\hline 1510 & 539 & 1561 & 1,274 & 1611 & 1,844 & 1661 & 2,998 & 1711 & 3,568 & 1761 & 4,847 & & \\
\hline 1511 & 551 & 1562 & 1,288 & 1612 & 1,883 & 1662 & 3,047 & 1712 & 3,542 & 1762 & 4,867 & & \\
\hline 1512 & 563 & 1563 & 1,303 & 1613 & 1,924 & 1663 & 3,093 & 1713 & 3,519 & 1763 & 4,888 & & \\
\hline 1513 & 576 & 1564 & 1,319 & 1614 & 1,966 & 1664 & 3,142 & 1714 & 3,526 & 1764 & 4,909 & & \\
\hline 1514 & 588 & 1565 & 1,336 & 1615 & 2,007 & 1665 & 3,194 & 1715 & 3,537 & 1765 & 4,930 & & \\
\hline 1515 & 601 & 1566 & 1,352 & 1616 & 2,050 & 1666 & 3,248 & 1716 & 3,554 & 1766 & 4,951 & & \\
\hline 1516 & 614 & 1567 & 1,369 & 1617 & 2,075 & 1667 & 3,300 & 1717 & 3,577 & 1767 & 4,972 & & \\
\hline 1517 & 627 & 1568 & 1,386 & 1618 & 2,094 & 1668 & 3,348 & 1718 & 3,605 & 1768 & 4,999 & & \\
\hline 1518 & 640 & 1569 & 1,405 & 1619 & 2,106 & 1669 & 3,393 & 1719 & 3,636 & 1769 & 5,026 & & \\
\hline 1519 & 652 & 1570 & 1,425 & 1620 & 2,117 & 1670 & 3,435 & 1720 & 3,667 & 1770 & 5,053 & & \\
\hline 1520 & 665 & 1571 & 1,446 & 1621 & 2,126 & 1671 & 3,473 & 1721 & 3,726 & 1771 & 5,080 & & \\
\hline 1521 & 678 & 1572 & 1,462 & 1622 & 2,133 & 1672 & 3,507 & 1722 & 3,773 & 1772 & 5,107 & & \\
\hline 1522 & 691 & 1573 & 1,489 & 1623 & 2,129 & 1673 & 3,538 & 1723 & 3,820 & 1773 & 5,134 & & \\
\hline 1523 & 704 & 1574 & 1,516 & 1624 & 2,127 & 1674 & 3,564 & 1724 & 3,861 & 1774 & 5,159 & & \\
\hline 1524 & 717 & 1575 & 1,543 & 1625 & 2,126 & 1675 & 3,587 & 1725 & 3,890 & 1775 & 5,189 & & \\
\hline
\end{tabular}


Table D.1 (continued)

\begin{tabular}{llllllllllll}
\hline 1525 & 729 & 1576 & 1,571 & 1626 & 2,121 & 1676 & 3,606 & 1726 & 3,921 & 1776 & 5,222 \\
1526 & 742 & 1577 & 1,599 & 1627 & 2,106 & 1677 & 3,608 & 1727 & 3,948 & 1777 & 5,257 \\
1527 & 754 & 1578 & 1,627 & 1628 & 2,111 & 1678 & 3,609 & 1728 & 3,943 & 1778 & 5,294 \\
1528 & 767 & 1579 & 1,654 & 1629 & 2,125 & 1679 & 3,611 & 1729 & 3,964 & 1779 & 5,333 \\
1529 & 780 & 1580 & 1,680 & 1630 & 2,147 & 1680 & 3,611 & 1730 & 3,984 & 1780 & 5,376 \\
1530 & 794 & 1581 & 1,705 & 1631 & 2,172 & 1681 & 3,611 & 1731 & 4,004 & 1781 & 5,402 \\
1531 & 808 & 1582 & 1,729 & 1632 & 2,202 & 1682 & 3,615 & 1732 & 4,024 & 1782 & 5,447 \\
1532 & 822 & 1583 & 1,752 & 1633 & 2,235 & 1683 & 3,620 & 1733 & 4,044 & 1783 & 5,493 \\
1533 & 836 & 1584 & 1,772 & 1634 & 2,279 & 1684 & 3,626 & 1734 & 4,064 & 1784 & 5,541 \\
1534 & 851 & 1585 & 1,788 & 1635 & 2,322 & 1685 & 3,633 & 1735 & 4,089 & 1785 & 5,592 \\
1535 & 865 & 1586 & 1,777 & 1636 & 2,366 & 1686 & 3,640 & 1736 & 4,126 & 1786 & 5,641 \\
1536 & 879 & 1587 & 1,779 & 1637 & 2,408 & 1687 & 3,647 & 1737 & 4,161 & 1787 & 5,688 \\
1537 & 894 & 1588 & 1,777 & 1638 & 2,469 & 1688 & 3,668 & 1738 & 4,198 & 1788 & 5,736 \\
1538 & 909 & 1589 & 1,772 & 1639 & 2,529 & 1689 & 3,690 & 1739 & 4,264 & 1789 & 5,784 \\
1539 & 924 & 1590 & 1,763 & 1640 & 2,587 & 1690 & 3,713 & 1740 & 4,303 & 1790 & 5,831 \\
1540 & 939 & 1591 & 1,752 & 1641 & 2,644 & 1691 & 3,735 & 1741 & 4,342 & 1791 & 5,879 \\
1541 & 954 & 1592 & 1,738 & 1642 & 2,698 & 1692 & 3,758 & 1742 & 4,380 & 1792 & 5,945 \\
\hline
\end{tabular}

Table D.2

Annual money supply estimate (tonnes).

\begin{tabular}{|c|c|c|c|c|c|c|c|c|c|c|c|c|c|}
\hline 1492 & 396 & 1543 & 981 & 1593 & 1,720 & 1643 & 2,779 & 1693 & 3,780 & 1743 & 4,423 & 1793 & 5,990 \\
\hline 1493 & 402 & 1544 & 997 & 1594 & 1,704 & 1644 & 2,824 & 1694 & 3,797 & 1744 & 4,463 & 1794 & 6,043 \\
\hline 1494 & 408 & 1545 & 1,014 & 1595 & 1,690 & 1645 & 2,869 & 1695 & 3,813 & 1745 & 4,503 & 1795 & 6,094 \\
\hline 1495 & 414 & 1546 & 1,034 & 1596 & 1,675 & 1646 & 2,913 & 1696 & 3,829 & 1746 & 4,534 & 1796 & 6,150 \\
\hline 1496 & 420 & 1547 & 1,054 & 1597 & 1,667 & 1647 & 2,954 & 1697 & 3,845 & 1747 & 4,564 & 1797 & 6,214 \\
\hline 1497 & 427 & 1548 & 1,074 & 1598 & 1,658 & 1648 & 2,987 & 1698 & 3,686 & 1748 & 4,594 & 1798 & 6,274 \\
\hline 1498 & 434 & 1549 & 1,094 & 1599 & 1,650 & 1649 & 3,021 & 1699 & 3,843 & 1749 & 4,622 & 1799 & 6,334 \\
\hline 1499 & 441 & 1550 & 1,106 & 1600 & 1,676 & 1650 & 3,056 & 1700 & 3,846 & 1750 & 4,639 & 1800 & 6,386 \\
\hline 1500 & 449 & 1551 & 1,126 & 1601 & 1,706 & 1651 & 3,087 & 1701 & 3,838 & 1751 & 4,666 & 1801 & 6,386 \\
\hline 1501 & 457 & 1552 & 1,146 & 1602 & 1,740 & 1652 & 3,115 & 1702 & 3,826 & 1752 & 4,642 & 1802 & 6,447 \\
\hline 1502 & 455 & 1553 & 1,164 & 1603 & 1,774 & 1653 & 3,144 & 1703 & 3,823 & 1753 & 4,676 & 1803 & 6,466 \\
\hline 1503 & 464 & 1554 & 1,109 & 1604 & 1,806 & 1654 & 3,173 & 1704 & 3,821 & 1754 & 4,700 & 1804 & 6,404 \\
\hline 1504 & 473 & 1555 & 1,152 & 1605 & 1,839 & 1655 & 2,948 & 1705 & 3,820 & 1755 & 4,724 & 1805 & 6,464 \\
\hline 1505 & 482 & 1556 & 1,171 & 1606 & 1,667 & 1656 & 2,763 & 1706 & 3,820 & 1756 & 4,747 & 1806 & 6,519 \\
\hline 1506 & 492 & 1557 & 1,190 & 1607 & 1,693 & 1657 & 2,856 & 1707 & 3,821 & 1757 & 4,771 & 1807 & 6,576 \\
\hline 1507 & 502 & 1558 & 1,210 & 1608 & 1,718 & 1658 & 2,879 & 1708 & 3,536 & 1758 & 4,794 & 1808 & 6,630 \\
\hline 1508 & 514 & 1559 & 1,228 & 1609 & 1,779 & 1659 & 2,905 & 1709 & 3,538 & 1759 & 4,821 & 1809 & 6,688 \\
\hline 1509 & 526 & 1560 & 1,250 & 1610 & 1,801 & 1660 & 2,929 & 1710 & 3,539 & 1760 & 4,848 & 1810 & 6,762 \\
\hline 1510 & 537 & 1561 & 1,275 & 1611 & 1,828 & 1661 & 2,966 & 1711 & 3,538 & 1761 & 4,875 & & \\
\hline 1511 & 549 & 1562 & 1,299 & 1612 & 1,868 & 1662 & 3,024 & 1712 & 3,539 & 1762 & 4,839 & & \\
\hline 1512 & 562 & 1563 & 1,299 & 1613 & 1,913 & 1663 & 3,080 & 1713 & 3,542 & 1763 & 4,865 & & \\
\hline 1513 & 575 & 1564 & 1,324 & 1614 & 1,959 & 1664 & 3,135 & 1714 & 3,581 & 1764 & 4,892 & & \\
\hline 1514 & 587 & 1565 & 1,348 & 1615 & 2,006 & 1665 & 3,191 & 1715 & 3,311 & 1765 & 4,918 & & \\
\hline 1515 & 601 & 1566 & 1,417 & 1616 & 2,053 & 1666 & 3,248 & 1716 & 3,485 & 1766 & 4,943 & & \\
\hline 1516 & 614 & 1567 & 1,331 & 1617 & 2,098 & 1667 & 3,305 & 1717 & 3,527 & 1767 & 4,968 & & \\
\hline 1517 & 627 & 1568 & 1,355 & 1618 & 2,141 & 1668 & 3,362 & 1718 & 3,570 & 1768 & 4,999 & & \\
\hline 1518 & 640 & 1569 & 1,384 & 1619 & 2,184 & 1669 & 3,421 & 1719 & 3,615 & 1769 & 5,027 & & \\
\hline 1519 & 653 & 1570 & 1,410 & 1620 & 2,229 & 1670 & 3,478 & 1720 & 3,661 & 1770 & 5,054 & & \\
\hline 1520 & 666 & 1571 & 1,433 & 1621 & 2,271 & 1671 & 3,518 & 1721 & 3,726 & 1771 & 5,081 & & \\
\hline 1521 & 678 & 1572 & 1,455 & 1622 & 2,103 & 1672 & 3,538 & 1722 & 3,786 & 1772 & 5,108 & & \\
\hline 1522 & 691 & 1573 & 1,485 & 1623 & 2,076 & 1673 & 3,557 & 1723 & 3,848 & 1773 & 5,135 & & \\
\hline 1523 & 704 & 1574 & 1,515 & 1624 & 2,051 & 1674 & 3,576 & 1724 & 3,884 & 1774 & 5,162 & & \\
\hline 1524 & 717 & 1575 & 1,544 & 1625 & 2,077 & 1675 & 3,594 & 1725 & 3,922 & 1775 & 5,189 & & \\
\hline 1525 & 729 & 1576 & 1,573 & 1626 & 2,102 & 1676 & 3,610 & 1726 & 3,961 & 1776 & 5,215 & & \\
\hline 1526 & 742 & 1577 & 1,599 & 1627 & 2,129 & 1677 & 3,624 & 1727 & 4,001 & 1777 & 5,242 & & \\
\hline 1527 & 755 & 1578 & 1,628 & 1628 & 2,060 & 1678 & 3,640 & 1728 & 4,041 & 1778 & 5,261 & & \\
\hline 1528 & 767 & 1579 & 1,654 & 1629 & 2,120 & 1679 & 3,654 & 1729 & 4,031 & 1779 & 5,281 & & \\
\hline 1529 & 780 & 1580 & 1,682 & 1630 & 2,173 & 1680 & 3,669 & 1730 & 3,932 & 1780 & 5,349 & & \\
\hline 1530 & 793 & 1581 & 1,711 & 1631 & 2,170 & 1681 & 3,683 & 1731 & 3,995 & 1781 & 5,414 & & \\
\hline 1531 & 804 & 1582 & 1,742 & 1632 & 2,101 & 1682 & 3,543 & 1732 & 4,022 & 1782 & 5,468 & & \\
\hline 1532 & 817 & 1583 & 1,763 & 1633 & 2,164 & 1683 & 3,556 & 1733 & 3,737 & 1783 & 5,515 & & \\
\hline 1533 & 829 & 1584 & 1,781 & 1634 & 2,232 & 1684 & 3,568 & 1734 & 4,074 & 1784 & 5,573 & & \\
\hline 1534 & 849 & 1585 & 1,800 & 1635 & 2,289 & 1685 & 3,580 & 1735 & 4,103 & 1785 & 5,625 & & \\
\hline 1535 & 870 & 1586 & 1,820 & 1636 & 2,355 & 1686 & 3,590 & 1736 & 4,143 & 1786 & 5,485 & & \\
\hline 1536 & 886 & 1587 & 1,842 & 1637 & 2,426 & 1687 & 3,661 & 1737 & 4,182 & 1787 & 5,706 & & \\
\hline 1537 & 896 & 1588 & 1,855 & 1638 & 2,491 & 1688 & 3,683 & 1738 & 4,222 & 1788 & 5,749 & & \\
\hline 1538 & 909 & 1589 & 1,844 & 1639 & 2,547 & 1689 & 3,704 & 1739 & 4,262 & 1789 & 5,793 & & \\
\hline 1539 & 923 & 1590 & 1,829 & 1640 & 2,597 & 1690 & 3,724 & 1740 & 4,303 & 1790 & 5,839 & & \\
\hline 1540 & 937 & 1591 & 1,559 & 1641 & 2,652 & 1691 & 3,744 & 1741 & 4,343 & 1791 & 5,885 & & \\
\hline 1541 & 951 & 1592 & 1,735 & 1642 & 2,631 & 1692 & 3,763 & 1742 & 4,383 & 1792 & 5,936 & & \\
\hline
\end{tabular}




\section{References}

Allen, R.C., 2001. The great divergence in European wages and prices from the Middle Ages to the First World War. Explor Econ Hist 38 (4), 411-447.

Álvarez-Nogal, C., Prados de la Escosura, L., 2013. The rise and fall of Spain (1270-1850). Econ Hist Rev 66 (1), 1-37.

Attman, A., 1986. American bullion in the European world trade 1600-1800. Acta Regiae Societatis Scientiarum Et Litterarum Gothoburgensis: Humaniora 26.

Amrhein, J., Jr, 2007. The Hidden Galleon. New Maritima Press.

Barrett, W., 1990. World bullion flows, 1450-1800. In: Tracy, J.D. (Ed.), The Rise of Merchant Empires: Long-distance Trade in the Early Modern World. Cambridge University Press.

Bolt, J., Inklaar, R., de Jong, H., van Zanden, J.L., 2018. Rebasing Maddison: New income comparisons and the shape of long-run economic development. Maddison Project Working paper 10. Maddison Project Database, version 2018.

Bonfatti, R., Brzezinski, A., Karaman, K.c.K., Palma, N., 2020. Monetary capacity. CEPR Discussion Paper No. DP15299.

Bonialian, M.A., 2012. El Pacífico hispanoamericano: Política y comercio asiático en el Imperio Español (1680-1784). El Colegio de Mexico AC.

Bonifacio, C., 2010. Galleons and sunken treasure. Signum Ops.

Borah, W.W., 1954. Early colonial trade and navigation between Mexico and Peru, 38-39. University of California Press.

Brading, D.A., Cross, H.E., 1972. Colonial silver mining: Mexico and Peru. Hispanic american historical review 52 (4), 545-579.

Braudel, F., Spooner, F., 1967. Prices in Europe from 1450 to 1750. The Cambridge Economic History of Europe 4, 374-486.

Bravo, M.S., 2010. Fragata "Santa Leocadia": episodios de su naufragio y rescate del tesoro. Revista del Instituto de Historica Marítima (46).

Brzezinski, A., Chen, Y., Palma, N., Ward, F., 2019. The vagaries of the sea: evidence on the real effects of money from maritime disasters in the Spanish Empire. CEPR Discussion Paper No. DP14089.

Bueno, P.E.P.-M., 1996. El hombre frente al mar: Naufragios en la Carrera de Indias durante los siglos XVI y XVII, 15. Universidad de Sevilla.

Carreras de Odriozola, A., Tafunell Sambola, X., 2006. Estadísticas históricas de España, siglos XIX-XX. Fundacion BBVA/BBVA Foundation.

Céspedes del Castillo, G., 1996. Las casas de moneda en los reinos de Indias: Las cecas indianas en 1536-1825. Museo Casa de la Moneda.

Challis, C.E., 1978. The Tudor Coinage. Manchester University Press.

Chen, Y., Palma, N., Ward, F., 2021. Data and Code for: Reconstruction of the Spanish Money Supply, 1492-1810. Ann Arbor, MI: Inter-university Consortium for Political and Social Research [distributor], 2021-05-04. doi: 10.3886/E139761V2.

Chevalier, M., 1847. Des mines d'argent et d'or du nouveau-monde considérées dans leur passé et leur avenir et comparées a celles de l'ancien continent. Au bureau de la Revue des deux mondes.

Chuan, H.-S., 1969. The inflow of American silver into China from the late ming to the mid-Ch'ing period. The Journal of the Institute of Chinese Studies of the Chinese University of Hong Kong 2, 61-75.

Chuan, H.-S., 1997. Trade between China, the Philippines and the Americas during the sixteenth and seventeenth centuries. In: Proceedings of the International Conference of Sinology: Selection on History and Archaeology, pp. 849-854.

Cobbett, W., 1804. Capture of Spanish frigates. Cobbett's Weekly Political Register.

Costa, L.F., Rocha, M.M., de Sousa, R.M., 2013. Ouro do Brasil. Imprensa Nacional-Casa da Moeda.

Cross, H.E., 1983. South American bullion production and export, 1550-1750. In: Richards, J.F. (Ed.), Precious Metals in the Later Medieval and Early Modern Worlds. Carolina Academic Press Durham, pp. 425-439.

de Vries, J., 2003. Connecting Europe and Asia: a quantitative analysis of the Cape-route trade, 1497-1795. In: Flynn, D.O., von Glahn, R., Giraldez, A. (Eds.), Global Connections and Monetary History, 1470-1800. Ashgate.

Del Mar, A., 1877. Minute on Population and Specie in the Western World. Report of the U.S. Monetary Commission, Washington.

Del Mar, A., 1877. Minute on the World's Production of Gold and Silver. Report of the U.S. Monetary Commission, Washington.

Desaulty, A.-M., Telouk, P., Albalat, E., Albarède, F., 2011. Isotopic Ag-Cu-Pb record of silver circulation through 16th-18th century Spain. Proceedings of the National Academy of Sciences 108 (22), 9002-9007.

Earle, P., 2007. Treasure Hunt: Shipwreck, Diving, and the Quest for Treasure in an Age of Heroes. Macmillan.

Elliott, J.H., 2006. Empires of the Atlantic World: Britain and Spain in America, 1492-1830. Yale University Press.

Fine, J.C., 2006. Treasures of the Spanish Main: Shipwrecked Galleons in the New World. Rowman \& Littlefield.

Fisher, D., 1989. The price revolution: a monetary interpretation. J Econ Hist 49 (4), 883-902.

Flandreau, M., 2004. The glitter of gold: France, bimetallism, and the emergence of the international gold standard, 1848-1973. Oxford University Press.

Flynn, D.O., 1978. A new perspective on the Spanish price revolution: the monetary approach to the balance of payments. Explor Econ Hist 15 (4), 388-406.

Flynn, D.O., Giraldez, A., 1995. Arbitrage, China, and world trade in the early modern period. Journal of the Economic and Social History of the Orient $429-448$.

Flynn, D.O., Giráldez, A., 2017. European Entry into the Pacific: Spain and the Acapulco-Manila Galleons. Routledge.

, 2013. In: Frenkel, J.A., Johnson, H.G. (Eds.), The monetary approach to the balance of payments (collected works of Harry Johnson). Routledge.

Fuentes, L.G., 1980. El comercio español con América, 1650-1700. Sevilla: Escuela de Estudios Hispano-Americanos.

Gallatin, A., 1830. Considerations on the currency and banking system of the United States. Carey \& Lea.

García-Baquero, A., 1996. Las remesas de metales preciosos americanos en el siglo XVIII: una aritmética controvertida. Hispania 56 (192), 203-266.

García-Baquero González, A., 2003. American gold and silver in the eighteenth century: from fascination to accounting. In: Flynn, D.O., von Glahn, R., Giraldez, A. (Eds.), Global connections and monetary history, 1470-1800. Ashgate, pp. 107-121.

Gentleman's, T., Magazine, L., 1763. Stated account of the sale of the hermione, and her cargo. Dublin: Printed by John Exshaw.

Glassman, D., Redish, A., 1985. New estimates of the money stock in France, 1493-1680. J Econ Hist 45 (1), 31-46.

Goldstone, J.A., 1984. Urbanization and inflation: lessons from the English price revolution of the sixteenth and seventeenth centuries. American Journal of Sociology 89 (5), 1122-1160.

Goldstone, J.A., 1991. Monetary versus velocity interpretations of the "Price Revolution": a comment. J Econ Hist 51 (1), $176-181$.

Hamilton, E.J., 1934. American treasure and the price revolution in Spain, 1501-1650, Vol. 1125. Harvard University Press Cambridge, MA.

Hamilton, E.J., 1947. War and prices in Spain: 1651-1800, Vol. 81. Harvard University Press Cambridge, MA.

Humboldt, A.v., 1811. Political essay on the Kingdom of New Spain, Vol. 1. Riley.

Hume, D., 1752. Political discourses. A. Kincaid \& A. Donaldson.

Irigoin, A., 2009. The end of a silver era: the consequences of the breakdown of the Spanish peso standard in China and the United States, 1780s-1850s. Journal of World History 20 (2), 207-244

Irigoin, A., 2020. Rise and demise of the global silver standard. In: Handbook of the History of Money and Currency. Springer, Singapore, pp. 383-410.

Jacob, W., 1831. An historical inquiry into the production, and consumption of the precious metals. Carey \& Lea.

Jara, A., 1966. Tres ensayos sobre economía minera hispanoamericana. Santiago de Chile: Prensas de la Editorial Universitaria, S. A., Centro de Investigaciones de Historia Americana, Universidad de Chile.

Kamen, H., 1966. The destruction of the Spanish silver fleet at Vigo in 1702. Historical Research 39 (100), $165-173$.

King, G., 1696. Natural and political observations and conclusions upon the state and condition of England.

Karaman, K.K., Pamuk, S., Yildırım, S., 2020. Money and monetary stability in Europe, 1300-1914. J Monet Econ 115, 279-300.

Legarda, B., 2017. Two and a Half Centuries of the Galleon Trade. In: Giraldez, A., Flynn, D.O. (Eds.), European Entry into the Pacific: Spain and the Acapulco-Manila Galleons. Routledge, pp. 337-365.

Lindert, P.H., 1985. English population, wages, and prices: 1541-1913. J Interdiscip Hist 15 (4), $609-634$.

Mateu y Llopis, F., 1942. Notas sobre cecas y monedas castellanas de los siglos XV y XVI. Boletín del Seminario de Estudios de Arte y Arqueología: BSAA (9) 45-58.

Mateu y Llopis, F., 1946. La moneda española (Breve historia monetaria de España). Editorial Alberto Martin.

Losa, E.L., Zarauz, S.P., 2020. Spanish subsistence wages and the little divergence in Europe, 1500-1800. Eur Rev Econ Hist. 
MacCulloch, J.R., 1855. A dictionary of commerce and commercial navigation, 3 Longmann. [1846]

Mangas, F.S., 1989. Armadas y flotas de la plata 1620-1640. Banco de España, Madrid.

Marx, R.F., 1987. Shipwrecks in the Americas. Courier Corporation.

Mayhew, N.J., 1974. Numismatic evidence and falling prices in the fourteenth century. Econ Hist Rev 27 (1), 1-15.

Mayhew, N.J., 1995. Population, money supply, and the velocity of circulation in England, 1300-1700. Econ Hist Rev 48 (2), $238-257$.

Mayhew, N.J., 2012. Silver in England 1600-1800: coinage outputs and bullion exports from the records of the London tower mind and the London Company of Goldsmiths. In: Munro, J. (Ed.), Money in the Pre-Industrial World: Bullion, Debasements and Coin Substitutes. Routledge.

Mayhew, N.J., 2013. Prices in England, 1170-1750. Past \& Present 219 (1), 3-39.

McConnell, J.R., Wilson, A.I., Stohl, A., Arienzo, M.M., Chellman, N.J., Eckhardt, S., Thompson, E.M., Pollard, A.M., Steffensen, J.P., 2018. Lead pollution recorded in Greenland ice indicates European emissions tracked plagues, wars, and imperial expansion during antiquity. Proceedings of the National Academy of Sciences 115 (22), 5726-5731.

Merrill, C.W., 1930. Summarized data of silver production. U.S. Department of Commerce, Economic Paper 8.

Miskimin, H.A., 1975. Population growth and the price revolution in England. Journal of European Economic History 4 (1), 179.

Moreno, J.V.T., 2014. Monedas de antiguo y nuevo cuño: envilecimiento y reacuñación en el nuevo reino de granada en la segunda mitad del siglo xviii. Memoria y Sociedad 18 (36), 121-136.

Morineau, M., 1985. Incroyables gazettes et fabuleux métaux: Les retours des trésors américains d'après les gazettes hollandaises (XVIe-XVIIIe siècles), Vol. 7. Les Editions de la MSH.

Motomura, A., 1994. The best and worst of currencies: Seigniorage and currency policy in Spain, 1597-1650. J Econ Hist 54 (1), $104-127$.

Motomura, A., 1997. New data on minting, seigniorage, and the money supply in Spain (Castile), 1597-1643. Explor Econ Hist 34, $331-367$.

Munro, J.H., 2003. The monetary origins of the "Price Revolution": South German silver mining, merchant banking, and Venetian commerce, 1470-1540. In: Global Connections and Monetary History, 1470-1800. Aldershot, pp. 1-34.

Munro, J.H., 2008. Money, prices, wages, and 'profit inflation' in Spain, the Southern Netherlands, and England during the price revolution era, ca. 1520 - ca. 1650. História e Economia: Revista Interdisciplinar 4 (1), 13-71.

Nef, J.U., 1941. Silver production in Central Europe, 1450-1618. Journal of Political Economy 49 (4), 575-591.

Nicolini, E.A., Ramos, F., 2010. A new method for estimating the money demand in pre-industrial economies: probate inventories and Spain in the eighteenth century. Eur Rev Econ Hist 14 (1), 145-177.

Nightingale, P., 1990. Monetary contraction and mercantile credit in later medieval England. Econ Hist Rev 43 (4), $560-575$.

Nogues-Marco, P., 2011. The microeconomics of bullionism: arbitrage, smuggling and silver outflows in Spain in the early 18th century. Universidad Carlos III de Madrid. Working Papers in Economic History, WP 11-05. https://e-archivo.uc3m.es/handle/10016/11425.

Palma, N., 2018. Reconstruction of money supply over the long run: the case of England, 1270-1870. Econ Hist Rev 71 (2), 373-392.

Palma, N., 2019. American precious metals and their consequences for early modern Europe. In: Battilossi, S., Cassis, Y., Kazuhiko, Y. (Eds.), Handbook of the History of Money and Currency. Springer.

Palma, N., 2021. The real effects of monetary expansions: evidence from a large-scale historical experiment. Rev Econ Stud forthcoming.

Pamuk, c., 2001. The price revolution in the Ottoman Empire reconsidered. Int J Middle East Stud 33 (1), 69-89.

Patterson, C.C., 1972. Silver stocks and losses in ancient and medieval times. Econ Hist Rev 25 (2), $205-235$.

de Paula, P.S.F., 2016. La casa de moneda de Sevilla, su historia. Universidad de Sevilla.

Peterson, M., 1975. The funnel of gold. Little, Brown, \& Company.

Phillips, C.R., 1990. The growth and composition of trade in the Iberian Empires, 1450-1750. In: Tracy, J.D. (Ed.), The rise of merchant empires: Long-distance trade in the early modern world 1350-1750. Cambridge University Press, pp. 34-101.

Phillips, C.R., 2007. The treasure of the San José: Death at sea in the War of the Spanish Succession. JHU Press.

Potter, J.S., 1972. The treasure diver's guide. Doubleday, New York.

Putley, J., 2000. The virgins' treasure isle. Virgin Island Books.

Ridgway, R. H., 1929. Summarized data of gold production. U.S. Department of Commerce, Economic Paper 6.

Sandz, V., Marx, R.F., 2001. Encyclopedia of Western Atlantic shipwrecks and sunken treasure. McFarland, London.

Sargent, T.J., Velde, F.R., 2002. The big problem of small change. Princeton University Press.

Schurz, W.L., 1939. The Manila Galleon, Vol. 40. Historical Conservation Society.

Sedgwick, R., 1970. The history of parliament: the house of commons, 1715-1754. Published for the History of Parliament Trust, by Oxford University Press.

Soetbeer, A., 1879. Edelmetall-Produktion und Werthverhältniss zwischen Gold and Silber seit der Entdeckung Amerika's bis zur Gegenwart. Justus Perthes.

Spooner, F.C., 1972. The international economy and monetary movements in France, 1439-1725. Harvard Economic Studies, Vol. 138. Harvard University Press.

Stengers, J., 2004. De la créance accordée aux chiffres sans valeur. Revue belge de Philologie et d'Histoire 82 (1), $215-227$.

TePaske, J.J., 2010. A New World of Gold and Silver. Brill.

Tortella, G., n.d. El circulante metálico en España finales del siglo XVIII: primeras aplicaciones de esta estimación para el cálculo de la renta nacional. Unpublished manuscript.

Tortella, G., Ruiz, J.G., Ruiz, J.L.G., 2013. Spanish money and banking: A history. Springer.

Tutino, J., 2017. The Mexican heartland: How communities shaped capitalism, a nation, and world history, 1500-2000. Princeton University Press.

Tutino, J., 2018. Mexico City, 1808: Power, sovereignty, and silver in an age of war and revolution. University of New Mexico Press.

Velde, F.R., 2013. On the evolution of specie: circulation and weight loss in 18th and 19th century coinage. Rev Numis 170, 605-650.

Velde, F.R., Weber, W.E., 2000a. Fiat money in 17th century Castile. Unpublished manuscript. https://www.researchgate.net/profile/Francois-Velde/publication/ 267848230_Fiat_Money_in_17th_Century_Castile/links/56c4d03f08aeeeffa9e5d9b4/Fiat-Money-in-17th-Century-Castile.pdf.

Velde, F.R., Weber, W.E., 2000b. A model of bimetallism. Journal of Political Economy 108 (6), 1210-1234.

Venema, J., 2010. Kiliaen van Rensselaer (1586-1643) Designing a New World. Uitgeverij Verloren.

Walton, T.R., 1994. The Spanish Treasure Fleets. Pineapple Press Inc.. 